\title{
Repetitive behavior profile and supersensitivity to amphetamine in the C58/J mouse model of autism
}

\author{
Sheryl S. Moy ${ }^{1,2,{ }^{*}}$, Natallia V. Riddick ${ }^{1,2}$, Viktoriya D. Nikolova ${ }^{2}$, Brian L. Teng ${ }^{1,3}$, Kara L. $^{1}$ \\ Agster $^{1,2}$, Randal J. Nonneman ${ }^{1,4}$, Nancy B. Young ${ }^{1,2}$, Lorinda K. Baker ${ }^{1,2}$, Jessica J. \\ Nadler $^{1,4,5}$, and James W. Bodfish ${ }^{1,2,6}$ \\ ${ }^{1}$ Carolina Institute for Developmental Disabilities, University of North Carolina School of Medicine, \\ Chapel Hill, NC 27599 \\ ${ }^{2}$ Department of Psychiatry, University of North Carolina School of Medicine, Chapel Hill, NC \\ 27599 \\ ${ }^{3}$ Department of Chemical Biology and Medicinal Chemistry, University of North Carolina School of \\ Medicine, Chapel Hill, NC 27599 \\ ${ }^{4}$ Department of Genetics, University of North Carolina School of Medicine, Chapel Hill, NC 27599
}

\begin{abstract}
Restricted repetitive behaviors are core symptoms of autism spectrum disorders (ASDs). The range of symptoms encompassed by the repetitive behavior domain includes lower-order stereotypy and self-injury, and higher-order indices of circumscribed interests and cognitive rigidity. Heterogeneity in clinical ASD profiles suggests that specific manifestations of repetitive behavior reflect differential neuropathology. The present studies utilized a set of phenotyping tasks to determine a repetitive behavior profile for the C58/J mouse strain, a model of ASD core symptoms. In an observational screen, C58/J demonstrated overt motor stereotypy, but not overgrooming, a commonly-used measure for mouse repetitive behavior. Amphetamine did not exacerbate motor stereotypy, but had enhanced stimulant effects on locomotion and rearing in C58/J, compared to C57BL/6J. Both C58/J and Grinl knockdown mice, another model of ASDlike behavior, had marked deficits in marble-burying. In a nose poke task for higher-order repetitive behavior, $\mathrm{C} 58 / \mathrm{J}$ had reduced holeboard exploration and preference for non-social, versus social, olfactory stimuli, but did not demonstrate cognitive rigidity following familiarization to an appetitive stimulus. Analysis of available high-density genotype data indicated specific regions of divergence between $\mathrm{C} 58 / \mathrm{J}$ and two highly-sociable strains with common genetic lineage. Strain genome comparisons identified autism candidate genes, including Cntnap2 and Slc6a4, located within regions divergent in C58/J. However, Grinl, Nlgn1, Sapap3, and Slitrk5, genes linked to repetitive over-grooming, were not in regions of divergence. These studies suggest that specific repetitive phenotypes can be used to distinguish ASD mouse models, with implications for divergent underlying mechanisms for different repetitive behavior profiles.
\end{abstract}

\footnotetext{
(C) 2013 Elsevier B.V. All rights reserved.

*Corresponding author: Sheryl S. Moy, Ph.D., Carolina Institute for Developmental Disabilities, CB\#7146, University of North Carolina School of Medicine, Chapel Hill, NC 27599, USA, Phone: (919) 966-3082, Fax: (919) 966-5657, ssmoy@ med.unc.edu. 5 Deloitte Consulting, Arlington, VA 22209.

${ }^{6}$ Departments of Psychiatry and Hearing \& Speech Sciences, Vanderbilt Kennedy Center, Nashville, TN 37203.

Publisher's Disclaimer: This is a PDF file of an unedited manuscript that has been accepted for publication. As a service to our customers we are providing this early version of the manuscript. The manuscript will undergo copyediting, typesetting, and review of the resulting proof before it is published in its final citable form. Please note that during the production process errors may be discovered which could affect the content, and all legal disclaimers that apply to the journal pertain.
} 


\section{Keywords}

autism spectrum disorder; circumscribed interests; hyperactivity; NMDA receptor; olfaction; SNP analysis

\section{Introduction}

The autism diagnostic profile includes three core symptoms: aberrant reciprocal social behavior, communication deficits, and restricted repetitive behaviors [1]. Within these core symptoms, there can be a high level of diversity in clinical presentation of autism spectrum disorders (ASDs). In particular, the range of defining characteristics for repetitive behavior spans lower-order symptoms, such as motor stereotypy and self-injurious responses, and higher-order symptoms that reflect cognitive rigidity, including an implacable resistance to change and deficits in flexible learning processes [2]. Dissection of the repetitive behavior domain using factor analysis has identified motor stereotypy, insistence on sameness, and narrow, circumscribed interests as three separate components [3], suggesting that subtypes of repetitive behavior could indicate different underlying genetic and brain abnormalities. In line with this premise, divergent profiles of repetitive behavior have been reported across genetic syndromes with ASD features [4,5].

The C58/J inbred mouse strain has a behavioral profile that reflects core symptoms in autism, including deficits in sociability, impaired communication, and overt motor stereotypy [6-10]. Abnormal repetitive behaviors include persistent cage-lid backflipping, jackhammer-like jumping, and wall climbing. In line with the emergence of ASD symptoms in early childhood, aberrant phenotypes can be observed in C58/J during the neonatal and weanling periods [7]. Previous reports have utilized the C57BL/6J inbred strain as a comparison group, based on close physical similarity to C58/J, and a genetic lineage overlapping with $\mathrm{C} 58 / \mathrm{J}$ through the paternal founder of the progenitor stock [11]. The present studies used a set of mouse tasks for lower-order and higher-order phenotypes to determine a repetitive behavior profile for C58/J. Since repetitive motor behavior is associated with abnormal activation of dopaminergic cortical-basal ganglia circuitry [1214], the studies investigated whether amphetamine could exacerbate stereotypy or have other divergent effects in C58/J, in comparison to C57BL/6J. In a subset of tasks, behavioral profiles in C58/J were compared with phenotypes in another model of aberrant repetitive responses, Grinl knockdown mice, which have constitutive disruption of NMDA-receptor function [15].

The marble-burying task has typically been used as a measure for anxiety in rodent models $[16,17]$. However, Thomas and colleagues [18] found that digging responses in this assay did not correlate with performance in the elevated plus maze or open field, two standard approaches to evaluate anxiety-like behavior in mice. The researchers suggested that, rather than a test for anxiogenic effects of novelty, marble-burying was an index for perseverative digging behavior. Supporting this premise, increased rates of marble-burying have been reported in the BTBR T+tf/J strain, a model for autism-like behavior [19], Slitrk5-null mice, which exhibit over-grooming and self-lesioning [20], and, dependent upon background strain, in Fmrl-null mice, a model of fragile X syndrome [21]. Thus, we predicted that C58/ $\mathrm{J}$ would demonstrate impulsive digging responses in this test, in line with the high rates of motor stereotypy observed in other experimental settings.

To further investigate marble-burying as an index of repetitive behavior, the present studies also assessed Grin $1^{\text {neo/neo }}$ (Grinl knockdown) mice in this task. Grinl ${ }^{\text {neo/neo }}$ mice, which have reduced NMDA receptor function, demonstrate spontaneous motor stereotypy, 
including over-grooming to the point of self-injury [22,23]. Similar to C58/J, Grin $I^{\text {neo/neo }}$ mice exhibit a range of deficient social responses [15,24,25]. In addition, the Grinl knockdown mice show overt abnormalities in extended open field tests and acoustic startle assays, including deficits in habituation, exaggerated startle responses, and impaired sensorimotor gating $[24,26,27]$, with aberrant phenotypes present during the neonatal period [28]. In children with autism, levels of repetitive behavior are positively correlated with general hyperactivity [29] and hyper-responsivity to sensory stimuli [30]. The present studies utilized open field and acoustic startle assays to examine whether C58/J was characterized by hyperactivity and altered sensory reactivity, similar to the Grin $1^{\text {neo/neo }}$ model.

Recent studies in subjects with autism have measured higher-order symptoms of repetitive behavior, such as restricted, circumscribed interests and unusual preoccupations, through eye movements directed towards pictures of objects presented on a computer screen [3133]. By tracking visual attention, investigators have found that children with ASD have generally reduced exploration of image arrays, increased preference for non-social, versus social, stimuli, and perseverative, inflexible attention directed towards specific pictures. In the present study, we used a nose poke test for mice, with arrays of floor holes and different olfactory stimuli, to model the arrays of visual stimuli used in human eye-tracking procedures [22]. The nose poke task provided measures of holeboard exploration and responses directed towards social and non-social olfactory stimuli as indices of restricted interests, atypical stimuli preference, and other features of higher-order repetitive behavior. C58/J was compared to $\mathrm{C} 57 \mathrm{BL} / 6 \mathrm{~J}$ and $\mathrm{C} 57 \mathrm{~L} / \mathrm{J}$, two inbred strains with overlapping genetic lineage [11], but without behavioral characteristics reflecting ASD-like symptoms [6,7,34]. To explore the genetic basis of abnormal phenotypes in C58/J, a single-nucleotide polymorphism (SNP) analysis was conducted, using published data on the genome of C58/J, C57BL/6J, and C57/L [35]. Previous work has identified significant quantitative trait loci for open field measures in $\mathrm{C} 58 / \mathrm{J} \times \mathrm{C} 57 \mathrm{BL} / 6 \mathrm{~J}$ intercross mice, supporting genetic divergence related to behavioral phenotypes in these two strains $[36,37]$.

\section{Materials and methods}

\subsection{Animals}

Sets of A/J, BALB/cByJ, C57BL/6J, C58/J, and C57L/J male mice, 3-4 weeks in age, were purchased from the Jackson Laboratory (JAX; Bar Harbor, ME). Separate sets of male and female C57BL/6J and C58/J mice were offspring of breeding pairs obtained from JAX.

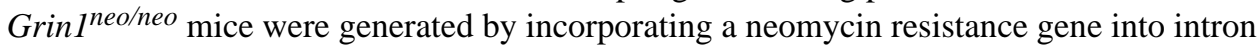
20 of the Grinl (NRI) locus, as previously described [15]. The mutation is currently maintained on an isogenic 129S6/SvEvTac (129S6) background and a C57BL/6J background (14N). Subjects in the present studies were littermate rrinl $^{+/+}$(wild-type), Grinl $^{+/ n e o}$ (heterozygous), and Grin $1^{\text {neo/neo }}$ (knockdown) F1 offspring of 129S6 and C57BL/6 heterozygous animals. Experimenters conducted studies blind to Grin1 genotype. All mice were group-housed in standard $20 \mathrm{~cm} \times 30 \mathrm{~cm}$ ventilated polycarbonate cages with food (LabDiet ProLab RMH 3000) and water available ad libitum. Animals were maintained on a 12L:12D light schedule with lights on at 7AM. Behavioral tests were performed during the light phase of the cycle. All procedures were designed to minimize pain and discomfort in the animals, and conducted in strict compliance with the "Guide for the Care and Use of Laboratory Animals" (Institute of Laboratory Animal Resources, National Research Council, 1996) and approved by the Institutional Animal Care and Use Committee of the University of North Carolina. 


\subsection{Drugs}

Amphetamine (D-amphetamine sulfate) and MK-801 ((+)-MK-801 hydrogen maleate) were purchased from Sigma Chemicals (St. Louis, IL), and administered at a volume of $1 \mathrm{ml} / 100$ g body weight by intraperitoneal (IP) injection, with saline vehicle. Dose concentration was based on the salt weight of each compound. On the day of testing, drug solutions were coded so that experimenters were blind to treatment.

\subsection{Testing regimens}

2.4.1. Amphetamine effects in an observational screen for repetitive behavior - C57BL/6J (11 males and 10 females) and C58/J (10 males and 15 females) mice, bred in the UNC animal facility, were evaluated for amphetamine $(2.0$ and $4.0 \mathrm{mg} / \mathrm{kg})$ effects on motor stereotypy during a 10-min screen (see below for detailed description). Mice were 89 weeks in age at the beginning of testing. Each subject was given 3 tests, with 1 week between each test, so that each mouse received 1 treatment with the low and high dose of amphetamine, and with vehicle. The order of the 3 treatments was balanced across strain, sex, and week. Amphetamine was administered 10 minutes before behavioral recording.

\subsubsection{Comparison of C58/J with Grin1 knockdown mice-C57BL/6J and C58/J} mice ( $\mathrm{N}=14$ males and 13 females for each strain), Grinl ${ }^{+/+}(11$ male and 11 female) and Grin $I^{\text {neo/neo }}$ (16 male and 8 female) mice, bred at UNC, were tested in a 2-hr open field test, a marble-burying assay, and an acoustic startle test, with 1 week between each procedure. Mice were 2-5 months in age at the time of testing.

2.4.3. Amphetamine effects on locomotion in an open field-A separate set of C57BL/6J ( 8 males and 8 females) and C58/J mice (11 males and 9 females), bred at UNC, were evaluated for amphetamine $(4.0 \mathrm{mg} / \mathrm{kg})$ effects on locomotion in a 2-hr open field test. Mice were 3-5 months in age at the time of testing. Each mouse was given 2 tests, with 1 week between each test. Either vehicle or amphetamine was administered immediately before the start of the test, so that each mouse received 1 treatment with amphetamine and with vehicle. Order of treatments was balanced across strain and sex.

\subsubsection{Additional groups in the marble-burying assay}

2.4.4.1. Effects of appetitive stimuli on reduced digging in C58/J: To further explore striking genotype effects in marble-burying, additional experimentally naïve groups were tested in this assay. Adolescent C57BL/6J and C58/J mice (6 weeks in age; 10 males and 10 females of each strain; bred at UNC) were evaluated for marble-burying with an appetitive stimulus (Cheerios) underneath the bedding. A separate set of male C57BL/6J and C58/J mice (4-6 months in age; bred at UNC) was tested for marble-burying in clean bedding, versus bedding with social stimuli (female cage bedding), with 9-10 mice of each strain in each condition.

2.4.4.2. Pharmacological disruption of NMDA receptor signaling: Results from the Grinl knockdown mice indicated that genetic reduction of NMDA receptor function led to marked decreases in marble-burying. To investigate the effects of acute reduction in NMDA receptor function on marble-burying, we administered an NMDA receptor antagonist, MK-801 $(0.2 \mathrm{mg} / \mathrm{kg})$, to a separate set of heterozygous and wild-type Grinl male mice. Subject numbers were $16 \mathrm{Grinl}^{+/ \text {neo }}(8$ vehicle and $8 \mathrm{MK}-801)$ and $7 \mathrm{Grinl}^{+/+}(3$ vehicle and 4 MK-801) mice, with treatment 20 min before the test.

2.4.4.3. Marble-burying in two inbred strains with low social approach: Our research group has previously reported that $\mathrm{BALB} / \mathrm{cByJ}$ and $\mathrm{A} / \mathrm{J}$ male mice do not have social 
preference in a 3-chamber choice task, and show low exploration in novel environments [34]. In our final marble-burying study, BALB/cByJ $(\mathrm{N}=12 ; \mathrm{JAX})$ and $\mathrm{A} / \mathrm{J}(\mathrm{N}=12 ; \mathrm{JAX})$ male mice were tested to determine whether these inbred strains would also exhibit deficits in digging, similar to the C58/J and Grin $1^{\text {neo/neo }}$ models of ASD-like behavior.

\subsubsection{Higher-order repetitive behavior in C58/J-C57BL/6J, C58/J, and C57L/J} male mice $(\mathrm{N}=10$ per strain; JAX) were first assessed in an elevated plus maze and 1-hr open field test, with 1 day between each procedure. Mice were $4-5$ weeks in age at the beginning of testing. Starting the following week, mice were evaluated in a series of 1-hr nose poke tests, using published procedures [22]: 2 tests of general exploration, 2 tests for familiarization to novel appetitive stimuli (conducted 1 week after the first 2 tests), and a test for preference for social olfactory stimuli (conducted at least 1 week following the previous test).

\subsection{Behavioral testing procedures}

2.5.1. Repetitive behavior screen-Ten minutes after vehicle or amphetamine injection, each mouse was removed from the home cage and placed singly into a clean, standard $20 \mathrm{~cm} \times 30 \mathrm{~cm}$ polycarbonate cage with bedding for a 10-min observation period. The incidence and amount of time each mouse spent executing the following behaviors was measured: cage-lid backflipping, jumping, rearing, grooming, digging, face-wiping, upright scrabbling or wall-climbing, and chewing on bedding. Activity during the test was measured by time spent locomoting. After the videos were first coded, each was re-scored with a new category, "hyperlocomotion," defined as rapid back-and-forth running. Video records were coded using the Observer software (Noldus Information Technology, Wageningen, the Netherlands) by experimenters blinded to drug treatment and strain.

2.5.2. Open field-Exploratory activity in a novel environment was assessed by $1 \mathrm{hr}$ or 2 $\mathrm{hr}$ tests in a photocell-equipped automated open field $(41 \mathrm{~cm} \times 41 \mathrm{~cm} \times 30 \mathrm{~cm}$; Fusion system or Versamax, Accuscan Instruments, Columbus, $\mathrm{OH}$ ). Measures were taken of total distance traveled, number of rearing movements, and time spent in the center during the test. Activity chambers were contained inside sound-attenuating boxes, equipped with ceiling lights and fans.

2.5.3. Marble-burying assay-Mice were tested in a Plexiglas cage located in a soundattenuating chamber with ceiling light and fan. The cage contained $5 \mathrm{~cm}$ deep clean corncob bedding, with 20 black glass marbles ( $14 \mathrm{~mm}$ diameter) arranged in an equidistant $5 \times 4$ grid on top of the bedding. Animals were given access to the marbles for $30 \mathrm{~min}$. Measures were taken of the number of buried marbles ( $2 / 3$ of the marble covered by the bedding) by two independent observers.

Two studies were conducted to investigate whether placement of food treats or social stimuli (taken from a cage of female mice) underneath the bedding could elicit digging in the C58/J strain. In the first study, mice were given 4-5 pieces of cereal (Frosted Cheerios; Kellogg Co., Battle Creek, MI) in their home cage 2-3 days before the test, so that the food treat was familiar. On the test day, 4 pieces of cereal were placed $2-3 \mathrm{~cm}$ underneath the bedding, and the marble-burying assay was conducted as described above. In the second study, $0.5 \mathrm{~L}$ of soiled bedding from a cage housing 3-4 female $\mathrm{C} 57 \mathrm{BL} / 6 \mathrm{~J}$ mice was distributed in the bottom of the test cage, and then covered with $2.5 \mathrm{~L}$ of clean bedding (for an overall depth of $5 \mathrm{~cm}$ ). The marble-burying assay was then conducted as described above.

2.5.4. Acoustic startle procedure-The acoustic startle measure was based on the reflexive whole-body flinch, or startle response, following exposure to a sudden noise. 
Animals were tested with a San Diego Instruments SR-Lab system, using published procedures [38,39]. Briefly, mice were placed in a small Plexiglas cylinder within a larger, sound-attenuating chamber. The cylinder was seated upon a piezoelectric transducer, which allowed vibrations to be quantified. The chamber included a ceiling light, fan, and a loudspeaker for the acoustic stimuli (bursts of white noise). Background sound levels (70 $\mathrm{dB}$ ) and calibration of the acoustic stimuli were confirmed with a digital sound level meter. Each test session consisted of 42 trials, presented following a 5-min habituation period. There were 7 types of trials: no-stimulus trials, trials with the acoustic startle stimulus (40 $\mathrm{ms} ; 120 \mathrm{~dB}$ ) alone, and trials in which a prepulse stimulus (20 ms; 74, 78, 82, 86, or $90 \mathrm{~dB}$ ) had onset $100 \mathrm{~ms}$ before the onset of the startle stimulus. The different trial types were presented in blocks of 7 , in randomized order within each block, with an average intertrial interval of $15 \mathrm{sec}$ (range: 10 to $20 \mathrm{sec}$ ). Measures were taken of the startle amplitude for each trial, defined as the peak response during a $65-\mathrm{ms}$ sampling window that began with the onset of the startle stimulus. Levels of PPI at each prepulse sound level were calculated as $100-[$ (response amplitude for prepulse stimulus and startle stimulus together/response amplitude for startle stimulus alone) $\times 100]$.

2.5.5. Elevated plus-maze test-Mice were given one 5-min trial on a metal plus-maze, which had two closed arms, with walls $20 \mathrm{~cm}$ in height, and two open arms. The maze was elevated $50 \mathrm{~cm}$ from the floor, and the arms were $30 \mathrm{~cm}$ long. Animals were placed on the center section $(8 \mathrm{~cm} \times 8 \mathrm{~cm})$, and allowed to freely explore the maze. Entries and time in each arm were recorded during the trial by a human observer.

\subsubsection{Nose poke tests for repetitive behavior}

2.5.6.1. Hole-board apparatus and olfactory stimuli: Nose poke responses were assessed during 1-hr tests in an open field chamber $(41 \mathrm{~cm} \times 41 \mathrm{~cm} \times 30 \mathrm{~cm})$ containing a floor-board with 16 equidistant holes. Nose pokes directed into the holes were counted by photobeams crossing each aperture (Pokemon system, Accuscan Instruments). Wire-mesh screens prevented mice from touching objects placed in the holes during the olfactory preference tests. Holeboards were removed after each test, washed with hot soapy water, and dried between subjects. Items for olfactory preference tests were placed in scintillation vial caps (Fisher Scientific, Pittsburgh, PA) and presented in one of the 4 center holes of the holeboard. New sets of olfactory stimuli were used for each mouse. Stimuli, described below, were selected for familiarity or possible appetitive or social valence. For each test, one center hole was left empty as a control for baseline nose poke levels.

Cage bedding stimuli: familiar clean cage bedding, the type used in the home cages of the subjects (approximately $1.5 \mathrm{~g}$ per sample, Bed-o-Cobs, The Andersons, Maumee, $\mathrm{OH}$ ), or novel cage bedding (Paperchip, Shepherd Specialty Papers, Plainwell, MI).

Appetitive stimuli: chocolate chips (Nestle, Vevey, Switzerland) and cereal (Froot Loops, Kellogg Co., Battle Creek, MI).

Social stimuli: male mouse urine ( $0.05 \mathrm{ml}$; CD1; Bioreclamation, Hicksville, NY), purchased as frozen $1-\mathrm{ml}$ samples and stored at $-20^{\circ} \mathrm{C}$ until the day of the test.

2.5.6.2. Tests for general exploration: One week after the plus maze and open field tests, mice were given 2 tests, on subsequent days, with no olfactory stimuli placed in the holes. Measures were taken of nose pokes into each hole, and duration of each nose poke, for each subject.

2.5.6.3. Familiarization tests: In the first 1-hr test, mice were presented with 3 olfactory stimuli in the center holes (familiar cage bedding, novel cage bedding, and a novel chocolate 
chip). Mice were then familiarized with the novel appetitive item by having 4-5 chocolate chips added to the home cages for the next 2 days. Following familiarization, mice were retested with the same 3 olfactory stimuli, including the familiar cage bedding and the nowfamiliar appetitive stimulus.

2.5.6.4. Appetitive versus social olfactory preference: In a final 1-hr test, mice were given a choice between a novel cereal (a Froot Loop) and a social olfactory stimulus (urine from an unfamiliar male mouse), as well as clean familiar cage bedding and an empty hole.

2.5.6.5. Criterion for hole preference in the nose poke task: To control for strain differences in total number of responses, the data for nose pokes per hole per subject were transformed to percent of total nose pokes per hole for each mouse. Criterion for preference for a particular hole was based on the expected frequency; i.e. if nose poke responses are evenly distributed across the 16 holes, percent of nose pokes per hole will average $6.25 \%$. Based on previous work [22], we have set a criterion of $12.5 \%$, or twice the expected average percent $(2 \times 6.25 \%)$, as an indication of high preference, and a criterion of $18.75 \%$, or three times the expected average percent $(3 \times 6.25 \%)$, as extreme preference. Low preference for a particular hole would be indicated by a percent of half the expected frequency $(3.125 \%)$.

\subsection{Statistical and genetic analyses}

2.6.1. Behavioral data analyses-Data were analyzed using 1-way, 2-way, or repeated measures ANOVAs, using Statview software (SAS, Cary, NC). In the repetitive behavior screen, within-strain repeated measures ANOVAs were used to determine effects of amphetamine. For the nose poke tests, within-strain repeated measures ANOVAs were used to determine significant hole preference. Fisher's protected least-significant difference (PLSD) tests were used for comparing group means only when a significant $\mathrm{F}$ value was determined in the ANOVAs. For all comparisons, significance was set at $\mathrm{p}<0.05$.

2.6.2. Single-nucleotide polymorphism (SNP) analysis-A SNP analysis was conducted, using published data on the genome of the C58/J, C57BL/6J, and C57L/J inbred strains [35], to identify regions of divergence between C58/J and strains with high sociability and low rates of repetitive behavior. Published genotype data, containing both experimentally determined and imputed SNPs for inbred strains (Mouse Genome Build 37) [35], were used to identify mouse homologs of autism candidate genes divergent in C58/J, in comparison to C57BL/6J and C57L/J. Identical-by-state (IBS) analysis was performed using the Center for Genome Dynamics (CGD) Strain Comparison Tool (Jackson Laboratory; http://cgd.jax.org/straincomparison). IBS regions were defined as genetic intervals where at least 10 contiguous SNPs were equivalent between the strains being compared. Regions identified as divergent between the 3 strains were further analyzed for overlap with genetic intervals containing 667 genes implicated in autism spectrum disorder (ASD) [40,41], using the CGD Genome Interval Overlap Calculator (http://cgd.jax.org/intervaloverlapcalculator). Identification and classification of variant SNPs within selected genes were determined using the CGD SNP Database (http://cgd.jax.org/cgdsnpdb/).

\section{Results}

\subsection{Amphetamine effects in an observational screen for repetitive behavior}

Work in animal models has implicated over-active dopaminergic transmission in abnormal repetitive behavior [12-14]. The present study investigated whether amphetamine ( 2 and 4 $\mathrm{mg} / \mathrm{kg}$ ) would exacerbate abnormal repetitive behavior in C58/J (Figure 1). Repeated measures ANOVAs did not indicate significant effects of sex on repetitive behavior, rearing, 
or locomotion, so data from males and females were combined. As previously reported, mice from the C58/J strain exhibited significantly higher levels of stereotyped responses (repeated cage-lid backflipping or "jackhammer" jumping; Figure 1A) than C57BL/6J [main effect of strain, $F(1,44)=9.77, p=0.0031]$. Surprisingly, neither dose of amphetamine had significant effects on overt repetitive behavior [treatment, $\mathrm{F}(2,88)=0.54, \mathrm{p}=0.5867$ ]. As shown in Figure 1B, amphetamine significantly increased number of rearing movements in C58/J, but not C57BL/6J, at both doses [main effect of strain, $F(1,44)=43.7$, $\mathrm{p}<0.0001$; treatment, $\mathrm{F}(2,88)=14.73$, $\mathrm{p}<0.0001$; strain $\times$ treatment interaction, $\mathrm{F}(2,88)=7.88, \mathrm{p}=0.0007]$.

As expected, amphetamine increased time spent in locomotion (Figure 1C), although activity was higher in C58/J mice [main effect of strain, $F(1,44)=8.24$, $p=0.0063$, and treatment, $F(2,88)=23.03$, $p<0.0001]$. During the first blinded coding of video records, the observers noted that some mice showed bouts of very rapid back-and-forth running in the cage. Therefore, the videos were re-coded to measure time spent in "hyperlocomotion" (Figure 1D). Interestingly, more than half of the C58/J mice (16/25), but none of the C57BL/ $6 \mathrm{~J}$ mice, showed bursts of rapid running during the observational screen.

No strain differences were found for grooming (Figure 1E), which was markedly decreased by amphetamine at either the high or low dose [treatment, $\mathrm{F}(2,88)=13.55, \mathrm{p}<0.0001]$. C58/J had very low levels of digging during the observational screen (Figure 1F). Amphetamine almost completely attenuated the higher rates of digging in the C57BL/6J mice [main effect of strain, $F(1,44)=46.15$, $p<0.0001$, and treatment, $F(2,88)=69.27$, $p<0.0001$; strain $\times$ treatment interaction, $F(2,88)=47.19, \mathrm{p}<0.0001]$. There were no significant effects of strain or amphetamine on face-wiping (data not shown). Two responses, wall-climbing and chewing on bedding, had very low incidence during the test (data not shown).

\subsection{Activity in a novel open field}

3.2.1. Total distance traveled in two models of repetitive behavior-In a novel open field, both the $\mathrm{C} 58 / \mathrm{J}$ and the Grin $1^{\text {neo/neo }}$ mice showed hyperlocomotion across almost all of the 2-hr activity test (Figure 2A, B). Data for male and female mice were combined, since overall repeated measure ANOVAs for distance traveled and rearing movements did not indicate significant main effects or interactions for sex in either the inbred strains or mutant lines. C58/J mice had significantly reduced distance traveled in the first $5 \mathrm{~min}$, and overt increases over most of the remaining intervals [post-hoc tests following repeated measures ANOVA; main effect of strain, $\mathrm{F}(1,51)=11.5, \mathrm{p}=0.0013$; strain $\times$ time interaction, $\mathrm{F}(23,1173)=4.0, \mathrm{p}<0.0001]$. In addition, C58/J exhibited a striking degree of variability in distance traveled, due to a subset of mice with extremely high levels of locomotion, and another subset with very low activity. In the Grinl lines, increased locomotion was found in the mutant mice for all but the first 5-min interval [main effect of genotype, $F(1,44)=27.4$, $\mathrm{p}<0.0001$; genotype $\times$ time interaction, $\mathrm{F}(23,1012)=2.5, \mathrm{p}<0.0001]$. Despite the large group differences in locomotion, there were no significant effects of either strain or genotype on time spent in the center regions (data not shown).

\subsubsection{Rearing movements in two models of repetitive behavior-A different} pattern was observed in the two inbred strains for the measure of rearing movements (Figure 2C). C58/J mice made fewer rears, in comparison to C57BL/6J, although the differences were only significant at three time points [post-hoc tests following repeated measures ANOVA; strain $\times$ time interaction, $\mathrm{F}(23,1173)=3.09, \mathrm{p}<0.0001]$. In contrast, the Grin 1 knockdown mice had robust hyperactivity by the rearing measure (Figure 2D) [main effect of genotype, $\mathrm{F}(1,44)=23.91$, $\mathrm{p}<0.0001$; genotype $\times$ time interaction, $\mathrm{F}(23,1012)=4.03$, $\mathrm{p}<0.0001]$, with a pattern very similar to the locomotion measure. 
3.2.3. Amphetamine effects on activity in C58/J-A separate set of C57BL/6J and C58/J mice were tested with amphetamine $(4 \mathrm{mg} / \mathrm{kg}$ ) in the open field, to further explore the hyperlocomotion phenotype and selective changes in rearing movements exhibited by C58/J in the observational screen. As shown in Figure 3B and C, mice from the C58/J strain had supersensitive responses to the stimulant effects of amphetamine. Increased levels of amphetamine-induced hyperlocomotion were clearly evident in C58/J across almost every time point. A repeated measures ANOVA indicated a significant 3-way interaction between strain, amphetamine treatment, and time $[\mathrm{F}(23,782)=5.49, \mathrm{p}<0.0001]$, a 2 -way interaction between strain and treatment $[\mathrm{F}(1,34)=18.53, \mathrm{p}<0.0001]$, and significant main effects of strain $[F(1,34)=43.13, p<0.0001]$ and treatment $[F(1,34)=124.68, p<0.0001]$. In addition, although the two strains had similar levels of rearing movements following vehicle, levels of amphetamine-induced rearing were markedly higher in the C58/J mice [3-way interaction between strain, amphetamine treatment, and time, $\mathrm{F}(23,782)=4.99$, $\mathrm{p}<0.0001 ; 2$-way interaction between strain and time, $\mathrm{F}(23,782)=7.34, \mathrm{p}<0.0001$; and main effect of treatment, $\mathrm{F}(1,34)=22.56, \mathrm{p}<0.0001]$.

The amphetamine study was conducted using a reversal treatment design, with each subject having two tests, separated by one week. Because the non-treated C58/J mice showed deficits in habituation (Figure 2A), the data for the amphetamine test were re-analyzed to investigate possible effects of order of treatment. Repeated measures ANOVAs revealed significant 3-way interactions between strain, treatment, and week of testing for distance traveled $[\mathrm{F}(1,32)=10.58, \mathrm{p}=0.0027]$ and for rearing $[\mathrm{F}(1,32)=8.26, \mathrm{p}=0.0071]$. Overall, the $\mathrm{C} 58 / \mathrm{J}$ mice in both the vehicle- and amphetamine- treated groups had higher levels of locomotor activity (Figure S1) and rearing (Figure S2) during the second test, in comparison to the first test. Although this study did not include a comparison group treated with vehicle for both tests, making it difficult to draw conclusions concerning order-of-treatment effects, the findings suggest that repeated testing in $\mathrm{C} 58 / \mathrm{J}$ can exacerbate hyperactivity and supersensitive responses to amphetamine (see Supplemental Data for detailed results).

\subsection{Marble-burying assay}

3.3.1. Reduced digging in $\mathbf{C 5 8} / \mathrm{J}$-In contrast to our prediction, $\mathrm{C} 58 / \mathrm{J}$ did not demonstrate perseverative digging in the marble-burying assay (Figure $4 \mathrm{~A}$ ). Both male and female $\mathrm{C} 58 / \mathrm{J}$ mice exhibited highly significant decreases in the number of marbles buried [2-way ANOVA; main effect of strain, $F(1,49)=129.3, p<0.0001$ ]. Although no sex differences were found, data are presented for both males and females to highlight the consistency of the unexpected findings.

3.3.2. Effects of appetitive and social stimuli-As shown in Figure $4 B$ and $C$, the striking strain differences in digging were still present with the addition of buried food treats [main effect of strain, $F(1,36)=130.29, \mathrm{p}<0.0001$ ] or an underlying layer of female cage bedding [main effect of strain, $\mathrm{F}(1,34)=94.00$, $\mathrm{p}<0.0001$ ]. When Cheerios were buried under the bedding, both C57BL/6J and C58/J mice were observed eating the cereal at the end of the test, indicating that at least some digging occurred in both strains. Overall, 2-way ANOVAs did not reveal any significant effects of either the buried food treat or female cage bedding on levels of marble-burying.

\subsubsection{Genetic and pharmacological disruption of NMDA signaling-A similar} pattern of deficient marble-burying (Figure 4D) was observed in the Grinl knockdown mice [main effect of genotype, $\mathrm{F}(1,42)=47.2, \mathrm{p}<0.0001$ ]. Although the 2-way ANOVA did not indicate any significant effects of sex, data from male and female groups are shown separately, to allow comparison to C58/J. As shown in Figure 4E, acute reduction in NMDA receptor function by a low dose of MK-801 $(0.2 \mathrm{mg} / \mathrm{kg})$ led to marked decreases in digging 
by Grin1 wild-type and heterozygous mice [main effect of treatment, $\mathrm{F}(1,19)=66.36$, $\mathrm{p}<0.0001]$. Thus, both constitutive and acute disruption of NMDA receptor function had similar effects in the marble-burying assay.

3.3.4. Marble-burying in two inbred strains with low social approach-We have found that the $\mathrm{BALB} / \mathrm{cByJ}$ and $\mathrm{A} / \mathrm{J}$ strains have a lack of social preference in a 3-chamber task and low levels of exploration in novel settings [34]. In the present study, BALB/cByJ mice showed robust marble-burying, while the A/J mice had more moderate digging (Figure 4F). These findings indicate that low rates of digging in the marble-burying task are not a general characteristic of strains with social deficits and low activity in other types of novel environments.

\subsection{Acoustic startle test in two models of repetitive behavior}

3.4.1. Amplitude of startle responses-Unlike the findings with the marble-burying assay, the C58/J and Grin $1^{\text {neo/neo }}$ mice demonstrated opposite behavioral phenotypes in the acoustic startle test. C58/J had decreased startle response amplitudes, in comparison to C57BL/6J (Figure 5A), with more overt strain differences in the male mice [repeated measures ANOVA, strain $\times$ decibel level $\times$ sex interaction, $\mathrm{F}(6,300)=3.5, \mathrm{p}=0.0023$; strain $\times$ decibel level interaction, $\mathrm{F}(6,300)=8.3$, $\mathrm{p}<0.0001$; and main effect of strain, $\mathrm{F}(1,50)=14.9$, $\mathrm{p}=0.0003$ ]. An opposite pattern was observed in the Grinl lines (Figure 5B), with highly significant increases in startle amplitudes found at every sound level [post-hoc tests following repeated measures ANOVA, genotype $\times$ decibel level interaction, $F(6,252)=21.1$, $\mathrm{p}<0.0001$; and main effect of genotype, $\mathrm{F}(1,42)=29.8, \mathrm{p}<0.0001]$. Although no effects of sex were determined in the Grinl lines, data from male and female mice are shown separately, to allow comparison with $\mathrm{C} 58 / \mathrm{J}$.

3.4.2. Prepulse inhibition of acoustic startle-The contrasting profiles in the two mouse models were also observed with the measure of prepulse inhibition, a commonlyused index of sensorimotor gating (Figure 6). Enhanced prepulse inhibition was evident in C58/J, with significant differences emerging in the female groups [repeated measures ANOVA, strain $\times$ decibel level $\times$ sex interaction, $F(4,200)=3.69$, $\mathrm{p}=0.0063$; strain $\times$ decibel level interaction, $\mathrm{F}(4,200)=4.18$, $\mathrm{p}=0.0028$; and main effect of strain, $\mathrm{F}(1,50)=7.67$, $\mathrm{p}=0.0079]$. In contrast, significant reductions in prepulse inhibition were found in the Grin $1^{\text {neo/neo }}$ mice, with the most overt deficits in the female groups [main effect of genotype, $\mathrm{F}(1,42)=10.59$, $\mathrm{p}=0.0022$; no effect of sex].

\subsection{Higher-order repetitive behavior in C58/J: comparison with C57BL/6J and C57L/J}

3.5.1. Anxiety-like behavior in an elevated plus maze-Before testing in the nosepoke assay, adolescent mice from the three strains were evaluated for anxiety-like behavior and activity. In line with previous findings [6], C58/J and C57BL/6J male mice had similar levels of percent time spent on the open arms of the elevated plus maze (Table 1). However, the $\mathrm{C} 57 \mathrm{~L} / \mathrm{J}$ mice had significantly higher open arm preference than either of the other strains [post-hoc tests following significant main effect of strain, $F(2,27)=19.8$, $p<0.0001$ ]. All three strains differed on percent entries into the open arms, with the C58/J mice having the lowest score, and $\mathrm{C} 57 \mathrm{~L} / \mathrm{J}$ the highest [post-hoc tests following significant main effect of strain, $\mathrm{F}(2,27)=17.1, \mathrm{p}<0.0001]$. Total number of entries, an index of overall activity, also varied between the strains $[\mathrm{F}(2,27)=28.0, \mathrm{p}<0.0001]$, with $\mathrm{C} 57 \mathrm{~L} / \mathrm{J}$ having twice the number of entries as $\mathrm{C} 57 \mathrm{BL} / 6 \mathrm{~J}$ and $\mathrm{C} 58 / \mathrm{J}$.

3.5.2. Activity in a novel open field-Significant strain differences in locomotor activity were observed in the adolescent mice $[\mathrm{F}(2,27)=6.84, \mathrm{p}=0.0039]$. $\mathrm{C} 58 / \mathrm{J}$ had higher levels of distance traveled than C57BL/6J during the 1-hr test (Table 1). The three strains 
also differed in the time spent exploring the center of the open field, another index of anxiety-like behavior in a novel environment. In line with the findings from the elevated plus maze, the $\mathrm{C} 57 \mathrm{~L} / \mathrm{J}$ mice spent more time in the center than the other two strains $[\mathrm{F}(2,27)=14.1, \mathrm{p}<0.0001]$.

\subsubsection{Nose poke task for exploration and olfactory preference}

3.5.3.1. Exploration tests: Previous work has shown that adolescent C57BL/6J mice tend to explore the entire hole-board, without overt hole preferences, during tests of general exploration without olfactory stimuli [22]. In the present study, all three strains showed a similar lack of hole preference during the first exploration test (Figure 7A). Percent total nose pokes did not reach a criterion for high (12.5\%) or low (3.125\%) preference for any of the holes. A lack of differential hole preference in all three strains was also observed in the second test, with the single exception of one center hole, to which the C57BL/6J mice directed only $3.01 \%$ of total nose pokes (data not shown).

3.5.3.2. Total number of nose poke responses: To investigate higher-order repetitive behaviors, the three strains were tested in several nose poke assays, first for general exploration without the addition of olfactory stimuli, and then for hole preference with social or appetitive olfactory stimuli. As shown in Figure 7C, the total number of nose pokes varied between the strains across the tests [repeated measures ANOVA on first 4 tests, main effect of strain, $\mathrm{F}(2,27)=9.0, \mathrm{p}=0.001$, and strain $\times$ test interaction, $\mathrm{F}(6,81)=3.3$, $\mathrm{p}=0.0058$ ]. Unfortunately, at the time of the final test with social olfactory stimuli, only 7 mice remained in the C58/J group, due to a malfunction of an automated cage watering system. The C58/J mice showed fewer nose poke responses than either of the other strains on the first day of testing, demonstrating less exploration of the novel hole-board.

3.5.3.3. Before familiarization to a novel appetitive stimulus: Olfactory preference was investigated by presenting familiar and novel stimuli in three of the four center holes: familiar clean cage bedding, novel clean paper chip cage bedding, and a novel chocolate chip. The fourth center hole was left empty as a control (Figure 8A). All three strains showed an expected pattern of high or extreme preference for the familiar cage bedding, as previously reported for $\mathrm{C} 57 \mathrm{BL} / 6 \mathrm{~J}$, BTBR T+tf/J, and FVB/NJ, as well as wild-type Grin 1 mice [22]. It is notable that, in this same task, Grin $1^{\text {neo/neo }}$ mice show similar preference for both the familiar and novel cage bedding [22]. In the present study, an ANOVA conducted on percent nose pokes directed towards the four center holes revealed a significant strain $\times$ hole interaction $[\mathrm{F}(6,81)=3.1, \mathrm{p}=0.0097]$. Post-hoc analyses indicated that the $\mathrm{C} 57 \mathrm{~L} / \mathrm{J}$ mice directed more nose pokes to the empty hole than the other two strains. An ANOVA conducted on the non-center holes (the corner and wall holes) did not indicate any differences between the strains. Further, the percent of total nose pokes did not reach the criterion for a high level of preference for any of the corner or wall holes.

3.5.3.4. Preference shift after familiarization to the appetitive stimulus: In the two days following the first test with olfactory stimuli, mice were familiarized to the novel appetitive stimulus by having several chocolate chips placed into their home cages, and then re-tested using the same set of olfactory stimuli in the center holes. As shown in Figure 8B, both the $\mathrm{C} 57 \mathrm{BL} / 6 \mathrm{~J}$ and the $\mathrm{C} 58 / \mathrm{J}$ mice had a striking shift in preference to the chocolate chip, following familiarization. A similar shift was observed in the C57L/J mice, but to a significantly lesser degree [main effect of strain, $F(2,27)=6.3$, $\mathrm{p}=0.0056$; strain $\times$ hole interaction, $\mathrm{F}(6,81)=11.2, \mathrm{p}<0.0001]$. We have previously found that Grin ${ }^{\text {neo/neo }}$ mice also exhibit a mild shift in preference following familiarization [22]. Interestingly, the BTBR $T$ $+t f / J$ strain, which is also characterized by repetitive over-grooming, fails to demonstrate any shift in preference after familiarization to a chocolate chip stimulus [22]. Overall, these 
results indicate that the $\mathrm{C} 58 / \mathrm{J}$ strain does not evidence cognitive rigidity following familiarization to appetitive stimuli in the holeboard task.

3.5.3.5. Preference for social versus non-social olfactory stimuli: The final nose poke test was used to determine preference for a novel social stimulus (urine from an unfamiliar CD-1 male mouse), in comparison to a novel food stimulus (Froot Loop breakfast cereal). An ANOVA conducted on percent nose pokes directed towards the olfactory stimuli revealed a significant strain $\times$ hole interaction $[\mathrm{F}(6,72)=5.2, \mathrm{p}=0.0002]$. The $\mathrm{C} 57 \mathrm{BL} / 6 \mathrm{~J}$ and $\mathrm{C} 57 \mathrm{~L} / \mathrm{J}$ mice, but not the $\mathrm{C} 58 / \mathrm{J}$ mice, had a high or extreme preference for the novel social stimuli (Figure $8 \mathrm{C}$ ). In contrast, C58/J had a significantly higher preference for the novel cereal, in comparison to the other two strains. C58/J also had lower investigation of the social stimulus and the empty hole, in comparison to $\mathrm{C} 57 \mathrm{~L} / \mathrm{J}$. No strain differences were found for the familiar bedding stimulus.

3.5.3.6. Duration of time per nose poke: In addition to number of nose pokes, measures were taken of duration of each nose poke during each holeboard test. As shown in Figures S3 and S4 of Supplementary Data, C58/J and C57BL/6J had comparable nose poke durations for almost every test. However, $\mathrm{C} 57 \mathrm{~L} / \mathrm{J}$ had significantly increased duration, in comparison to both other strains, during the first test of general exploration $[\mathrm{F}(2,27)=8.54$, $\mathrm{p}=0.0013]$, the olfactory test before familiarization $[\mathrm{F}(2,27)=5.27, \mathrm{p}=0.0117]$, and the final olfactory test with social stimuli $[\mathrm{F}(2,24)=6.66, \mathrm{p}=0.005]$ (see Supplementary Data for detailed results).

\subsection{Genetic comparison of the three inbred strains}

The present findings support the $\mathrm{C} 58 / \mathrm{J}$ strain as a model for different aspects of repetitive behavior, including overt motor stereotypy and reduced exploration in complex novel environments. An identical-by-state (IBS) analysis was conducted to test the possibility that autism-like phenotypes in C58/J could be associated with variation in genes proposed as candidates for autism susceptibility. The IBS analysis identified genomic regions that were either identical or divergent between C58/J and the two control strains (C57BL/6J and $\mathrm{C} 57 \mathrm{~L} / \mathrm{J}$ ) with similar genetic lineage. These regions were further tested for overlap with the mouse homologs of 667 ASD candidate genes, taken from a large-scale analysis of haplotype homozygosity between ASD subjects [40], and from a broad review of heritable factors linked to the ASDs [41]. In a comparison of all three strains, 426 of 667 ASD candidate genes (64\%) were located in genetic intervals identical between C57BL/6J, C57L/ $\mathrm{J}$, and C58/J, suggesting that allelic variants of these genes did not contribute to observed behavioral differences (Figure 9). Using pairwise IBS analyses, 97 ASD candidate genes $(15 \%)$ were determined to be identical between the control strains, but divergent in C58/J. Another 25 ASD candidate genes (4\%) overlapped with genetic intervals that were divergent among all three strains. It is possible that SNPs in these regions of divergence could function as heritable factors in strain-specific behavioral phenotypes.

\section{Discussion}

The restricted repetitive behavior domain in ASD symptomatology encompasses a wide range of abnormal phenotypes, reflecting the heterogeneity and complexity of ASD etiology. Clinical researchers have proposed that divergent profiles of repetitive behavior could serve as diagnostic indicators for autism subtypes and specific genetic syndromes [3,4,42-45]. Mouse models of ASD can be used to elucidate the genetic underpinnings of repetitive phenotypes, but require behavioral assays for lower-order and higher-order aspects of the repetitive behavior domain, including circumscribed interests, unusual occupations, and resistance to change. The present studies demonstrated that, in addition to spontaneous 
motor stereotypy [6-10], the C58/J mouse strain has a broader range of behavioral abnormalities, including restricted exploration of a novel holeboard and an "extreme" preference for a nonsocial, versus social, olfactory stimulus during the nose poke task. However, C58/J did not evidence a resistance to change following familiarization to an appetitive stimulus. The highly-significant alterations in open field locomotion and in marble-burying exhibited by C58/J were similar in severity to phenotypes in Grin $1^{\text {neo/neo }}$ mice, a model of repetitive behavior associated with profound NMDA receptor deficiency [15]. However, the C58/J strain differed from Grin $I^{\text {neo/neo }}$ mice in rearing movements, magnitude of acoustic startle responses, and changes in prepulse inhibition. These findings of divergent profiles in the two models provide evidence for different etiologies and underlying mechanisms in repetitive behavior phenotypes.

One measure that did not reveal abnormalities in C58/J was self-grooming, a response often reported as an index of repetitive behavior in ASD mouse models, including Grin $1^{\text {neo/neo }}$ mutant mice [22]. In line with these findings, SNP analyses did not identify Grinl, Nll, Sapap3, and Slitrk5, genes associated with mouse over-grooming phenotypes [20,22,46,47], as divergent in C58/J. In a recent report, Muehlmann and colleagues [9] confirmed spontaneous motor stereotypy in C58/J, without concomitant over-grooming. However, in contrast to the present findings, these researchers did not observe deficits in marble-burying by $\mathrm{C} 58 / \mathrm{J}$, and found increased numbers of nose-poke responses during general exploration of a hole-board. Muehlmann et al. [9] also showed striking effects of enriched housing conditions on stereotypy in C58/J, suggesting that this strain is particularly susceptible to environmental factors in the emergence of abnormal phenotypes. Thus, it is possible that differences in housing and laboratory environments could underlie the divergent results from the marble-burying and nose-poke tasks between our two research groups.

\subsection{Supersensitive responses to amphetamine in $\mathrm{C} 58 / \mathrm{J}$}

An issue for treating comorbid symptoms of attention-deficit/hyperactivity disorder (ADHD) in children with ASD is that stimulant compounds, such as methylphenidate, have a higher frequency of detrimental effects in autism patients, and might not be advisable in cases of stereotypy [48]. Work in animal models has implicated over-activation of dopaminergic cortical-basal ganglia circuitry in abnormal stereotypy [12-14]. Treatment with amphetamine, apomorphine, and other psychostimulant drugs can induce overt repetitive behavior in mice, including intense sniffing restricted to one location, headweaving, wall-climbing, gnawing, and licking, as well as hyperlocomotion [49-52]. Further, supersensitive responses to amphetamine challenge can reveal underlying abnormalities in dopamine function induced by genetic vulnerability, environmental stressors, or repeated exposure to psychostimulants [53-56]. Increased locomotor responses to amphetamine have been observed in mouse models of neurodevelopmental disorders, such as the BTBR $\mathrm{T}+t f / \mathrm{J}$ strain [57], and in mice with conditional expression of a human DISC1 mutation [58]. In addition, we have previously reported supersensitivity to amphetamine effects on acoustic startle amplitudes and prepulse inhibition in Grin $1^{\text {neo/neo }}$ mice [27]. In the present studies, acute treatment with amphetamine did not exacerbate motor stereotypy in C58/J, or induce unusual repetitive behavior in C57BL/6J. However, C58/J had markedly enhanced sensitivity to amphetamine effects on locomotion and rearing responses, providing evidence for intrinsic alterations in dopaminergic signaling pathways.

\subsection{Behavioral phenotypes in $\mathrm{C} 58 / \mathrm{J}$ and Grin1 knockdown mice}

Increased self-grooming is frequently used as an index of repetitive behavior in mice $[20,46,47,59]$. We have previously reported that Grin $1^{\text {neo/neo }}$ mice demonstrate compulsive grooming, to the point of self injury [22]. C58/J mice can also show exaggerated grooming, although the phenotype is not consistently observed across different ages [7], see also [9], 
and was not found in the present study. Thus, one question addressed by these studies was whether the marble-burying task could be used as a common measure of repetitive behavior for both C58/J and Grin $1^{\text {neo/neo }}$ mice. High rates of marble-burying have previously been reported in two mouse models characterized by over-grooming, the BTBR $\mathrm{T}+t f / \mathrm{J}$ strain and Slitrk5 knockout mice $[19,20]$. However, our results showed that both the C58/J and Grin $1^{\text {neo/neo }}$ mice had overt reductions in numbers of marbles buried. Although Muehlmann and colleagues [9] did not find significant reductions in marble-burying in C58/J, the researchers did observe a negative correlation between repetitive behaviors and number of marbles buried. Decreased marble-burying has been observed in other mouse models with autism-like phenotypes [60-62], suggesting that marble-burying could serve as an index for reduced exploration in a complex environment, relevant to symptoms in autism.

Both the C58/J and Grin $I^{\text {neo/neo }}$ mice demonstrated hyperlocomotion and deficits in habituation during the two-hour open field test, but had different profiles for the measure of rearing movements. In the C58/J mice, rearing was significantly decreased, while the Grin $I^{\text {neo/neo }}$ mice exhibited robust increases in vertical activity. Different profiles were also observed in the acoustic startle test. The Grin $1^{\text {neo/neo }}$ mice had increased levels of startle and impaired prepulse inhibition, as previously reported [24,26,27]. In contrast, the C58/J mice had lower startle amplitudes and, in the females, enhanced prepulse inhibition, which does not recapitulate the impaired sensorimotor gating observed in autism and related neurodevelopmental disorders [63-65]. However, similar lower startle amplitudes and enhanced prepulse inhibition have been reported in heterozygous mice with deficient function of Gabrb3, a candidate gene for autism susceptibility [62], and in Fmrl-null mice, a model for fragile $\mathrm{X}$ syndrome [21,63,66,67]. Overall, our results demonstrate both overlapping and divergent phenotypes in C58/J and Grin $1^{\text {neo/neo }}$ mice, indicating differential pathophysiology underlying abnormal behaviors in the two mouse models.

\subsection{Higher order repetitive behavior in a nose-poke task}

In comparison to typically-developing controls, children with autism have reduced exploration of novel objects or images, greater perseverative fixation on specific stimuli of interest, and a relative preference for images of nonsocial, versus social, objects [31-33,68]. The attentional bias for non-social images emerges very early in childhood, thus setting the stage for abnormal developmental trajectories relevant to restricted repetitive behavior in ASD [33]. In the present study, C58/J demonstrated general increases in locomotor activity in a novel open field, yet had significantly less exploration of the more complex holeboard environment. In contrast to C57BL/6J and C57L/J, C58/J had a strong preference for a nonsocial olfactory stimulus (cereal), rather than a social stimulus (mouse urine). Although C58/ $\mathrm{J}$ did not demonstrate cognitive rigidity following familiarization to a food stimulus, the bias shown by this strain towards non-social stimuli could reflect the unusual and circumscribed interests associated with ASD. It is notable that the BTBR $T+t f / \mathrm{J}$ strain also has reduced holeboard exploration, and retains an extreme preference for familiar cage bedding after familiarization, rather than showing the typical shift to the food stimulus [22]. Grin $1^{\text {neo/neo }}$ mice, on the other hand, exhibit higher levels of holeboard exploration than wild-type mice, and an atypical pattern of olfactory preference [22]. Thus, the nose poke task appears to be a useful tool for identifying divergent phenotypes in models of repetitive behavior, but further work is needed to determine whether resistance to shifts in preference, as seen in BTBR $T$ $+t f / \mathrm{J}$, or an atypical preference for non-social novel stimuli, as found in C58/J, can be observed across larger arrays of olfactory stimuli and multiple presentations, similar to the eye-tracking procedures used in human ASD subjects. 


\subsection{Mouse homologs of ASD-candidate genes divergent in $\mathrm{C} 58 / \mathrm{J}$}

The availability of dense genotypic data for many inbred mouse strains provides the opportunity to investigate the heritable basis for complex, strain-specific behavioral profiles, and to identify genes that might contribute to autism-like phenotypes. In this study, IBS analysis was used to identify genomic regions that are divergent in the C58/J strain, in comparison to $\mathrm{C} 57 \mathrm{BL} / 6 \mathrm{~J}$ and $\mathrm{C} 57 \mathrm{~L} / \mathrm{J}$. We then determined the distribution of mouse homologs for 667 ASD-associated genes [40,41] across identical and divergent genomic regions in the three strains, and found 97 of the genes resided within genetic intervals unique to C58/J. For example, Cntnap2, Discl, and Slc6a4 were all located in regions divergent in $\mathrm{C} 58 / \mathrm{J}$ (Table 2). Targeted disruption of these genes in mice can lead to deficits in sociability [69-71]. In addition, Cntnap 2 knockout mice show hyperactivity and repetitive overgrooming [69]. The divergent regions included sections of mouse chromosome 7 containing genes for three $\gamma$-amino-butyric acid (GABA) receptors, Gabrb3, Gabrg3 and Gabra5. Mice bearing a targeted disruption of the Gabrb3 locus exhibit impaired social and exploratory behaviors [72], and heterozygous Gabrb3 mice show reduced marble-burying, decreased acoustic startle responses, and enhanced prepulse inhibition [62].

Interestingly, several of the divergent SNPs in C58/J were located in intronic and/or exonic regions, with possible consequences for gene function. Variant SNPs were found in the intronic and 3' UTR regions of the Gabra5 and Gabrbl genes. Although their polypeptide sequences would not be altered, SNPs in these regions could have effects on GABA receptor expression levels, in line with alterations in GABRA5 and GABRB1 found in specific brain areas of autistic subjects [73]. In contrast, some SNPs in Cacnalc, Cntnap2, and Slc6a4 would be predicted to cause missense mutations, which could alter the function of encoded proteins in C58/J mice. For example, the polymorphism in Slc6a4, a regulator of serotonin reuptake, leads to G39E and K152R mutations, which have been shown to increase activity of the serotonin transporter [74]. This same Slc6a4 variant is found in the BALB/cJ strain, another model of sociability deficits $[75,76]$. Both $\mathrm{C} 58 / \mathrm{J}$ and BALB/cJ also harbor a missense mutation in Cntnap2 (H538Q), an autism susceptibility gene with variants linked to cases of ASD [77,78]. Additional polymorphisms identified in C58/J included SNPs in a region of chromosome 2 that contains 18 olfactory receptor genes, which could play a role in altered social behavior and olfactory preference.

In confirmation with divergent phenotypes in Grinl knockdown mice, the Grinl gene was not included in loci that have distinctive polymorphism between C58/J, C57BL/6J and C57L/J (Table 2). Three other genes implicated in repetitive grooming behavior, Nlgnl, Sapap3, and Slitrk5 [20,46,47], were also in regions identical between the three strains. Thus, both the behavioral and genetic analyses support divergent pathways underlying different forms of repetitive phenotypes. Overall, this combination of comparative behavioral phenotyping and genetic analyses appears to be a useful tool for probing the etiology of complex behavior. One caveat is that databases of high-throughput and imputed data, such as the CGD SNP database, can draw from sources with discrepant findings, indicating the importance of secondary verification for specific polymorphisms. Further bioinformatic analyses, such as screens for copy number variation and gene expression profiles in brain, could allow the identification of other heritable factors underlying autismlike phenotypes in mice, and the translation of these discoveries to human disorders.

\section{Supplementary Material}

Refer to Web version on PubMed Central for supplementary material. 


\section{Acknowledgments}

Support for these studies was contributed by NIMH grants MH084132, MH080069, MH73402, NICHD grant P30 HD03110, and NIH STAART grant U54 MH66418. Brian L. Teng was funded by an Autism Speaks Translational Postdoctoral Fellowship (\#7952). These sponsors did not have involvement in study design, data collection, analysis, or interpretation, writing the report, or decision to submit the article for publication. We are grateful for the contribution of Leah Jania and Rebecca Dye, who conducted the genotyping assays for the Grin1 mice.

\section{References}

1. American, Diagnostic and Statistical Manual of Mental Disorders (DSM-IV). American Psychiatric Association; Washington, DC: 2000.

2. Turner M. Annotation: Repetitive behaviour in autism: a review of psychological research. J Child Psychol Psychiatry. 1999; 40:839-849. [PubMed: 10509879]

3. Lam KS, Bodfish JW, Piven J. Evidence for three subtypes of repetitive behavior in autism that differ in familiality and association with other symptoms. J Child Psychol Psychiatry. 2008; 49:1193-1200. [PubMed: 19017031]

4. Moss J, Howlin P. Autism spectrum disorders in genetic syndromes: implications for diagnosis, intervention and understanding the wider autism spectrum disorder population. J Intellect Disabil Res. 2009; 53:852-873. [PubMed: 19708861]

5. Wolff JJ, Bodfish JW, Hazlett HC, Lightbody AA, Reiss AL, Piven J. Evidence of a distinct behavioral phenotype in young boys with fragile X syndrome and autism. J Am Acad Child Adolesc Psychiatry. 2012; 51:1324-1332. [PubMed: 23200289]

6. Moy SS, Nadler JJ, Young NB, Nonneman RJ, Segall SK, Andrade GM, Crawley JN, Magnuson TR. Social approach and repetitive behavior in eleven inbred mouse strains. Behav Brain Res. 2008; 191:118-129. [PubMed: 18440079]

7. Ryan BC, Young NB, Crawley JN, Bodfish JW, Moy SS. Social deficits, stereotypy and early emergence of repetitive behavior in the C58/J inbred mouse strain. Behav Brain Res. 2010; 208:178-188. [PubMed: 19941908]

8. Silverman JL, Smith DG, Rizzo SJ, Karras MN, Turner SM, Tolu SS, Bryce DK, Smith DL, Fonseca K, Ring RH, Crawley JN. Negative allosteric modulation of the mGluR5 receptor reduces repetitive behaviors and rescues social deficits in mouse models of autism. Sci Transl Med. 2012; 4:131-151.

9. Muehlmann AM, Edington G, Mihalik AC, Buchwald Z, Koppuzha D, Korah M, Lewis MH. Further characterization of repetitive behavior in C58 mice: developmental trajectory and effects of environmental enrichment. Behav Brain Res. 2012; 235:143-149. [PubMed: 22963990]

10. Teng BL, Nonneman RJ, Agster KL, Nikolova VD, Davis TT, Riddick NV, Baker LK, Pedersen CA, Jarstfer MB, Moy SS. Prosocial effects of oxytocin in two mouse models of autism spectrum disorders. Neuropharmacology. 2013; 72C:187-196. [PubMed: 23643748]

11. Tucker PK, Lee BK, Lundrigan BL, Eicher EM. Geographic origin of the Y chromosomes in "old" inbred strains of mice. Mamm Genome. 1992; 3:254-261. [PubMed: 1353382]

12. Lewis MH, Tanimura Y, Lee LW, Bodfish JW. Animal models of restricted repetitive behavior in autism. Behav Brain Res. 2007; 176:66-74. [PubMed: 16997392]

13. Muehlmann AM, Lewis MH. Abnormal repetitive behaviours: shared phenomenology and pathophysiology. J Intellect Disabil Res. 2012; 56:427-440. [PubMed: 22283923]

14. Langen M, Kas MJ, Staal WG, van Engeland H, Durston S. The neurobiology of repetitive behavior: of mice. Neurosci Biobehav Rev. 2011; 35:345-355. [PubMed: 20156480]

15. Mohn AR, Gainetdinov RR, Caron MG, Koller BH. Mice with reduced NMDA receptor expression display behaviors related to schizophrenia. Cell. 1999; 98:427-436. [PubMed: 10481908]

16. Njung'e K, Handley SL. Evaluation of marble-burying behavior as a model of anxiety. Pharmacol Biochem Behav. 1991; 38:63-67. [PubMed: 2017455]

17. Borsini F, Podhorna J, Marazziti D. Do animal models of anxiety predict anxiolytic-like effects of antidepressants? Psychopharmacology (Berl). 2002; 163:121-141. [PubMed: 12202959] 
18. Thomas A, Burant A, Bui N, Graham D, Yuva-Paylor LA, Paylor R. Marble burying reflects a repetitive and perseverative behavior more than novelty-induced anxiety. Psychopharmacology (Berl). 2009; 204:361-373. [PubMed: 19189082]

19. Amodeo DA, Jones JH, Sweeney JA, Ragozzino ME. Differences in BTBR T+ tf/J and C57BL/6J mice on probabilistic reversal learning and stereotyped behaviors. Behav Brain Res. 2012; 227:6472. [PubMed: 22056750]

20. Shmelkov SV, Hormigo A, Jing D, Proenca CC, Bath KG, Milde T, Shmelkov E, Kushner JS, Baljevic M, Dincheva I, Murphy AJ, Valenzuela DM, Gale NW, Yancopoulos GD, Ninan I, Lee FS, Rafii S. Slitrk5 deficiency impairs corticostriatal circuitry and leads to obsessive-compulsivelike behaviors in mice. Nat Med. 2010; 16:591-602.

21. Spencer CM, Alekseyenko O, Hamilton SM, Thomas AM, Serysheva E, Yuva-Paylor LA, Paylor R. Modifying behavioral phenotypes in Fmr1KO mice: genetic background differences reveal autistic-like responses. Autism Res. 2011; 4:40-56. [PubMed: 21268289]

22. Moy SS, Nadler JJ, Poe MD, Nonneman RJ, Young NB, Koller BH, Crawley JN, Duncan GE, Bodfish JW. Development of a mouse test for repetitive, restricted behaviors: Relevance to autism. Behav Brain Res. 2008; 188:178-194. [PubMed: 18068825]

23. Gandal MJ, Anderson RL, Billingslea EN, Carlson GC, Roberts TP, Siegel SJ. Mice with reduced NMDA receptor expression: more consistent with autism than schizophrenia? Genes Brain Behav. 2012; 11:740-750. [PubMed: 22726567]

24. Duncan GE, Moy SS, Perez A, Eddy DM, Zinzow WM, Lieberman JA, Snouwaert JN, Koller BH. Deficits in sensorimotor gating and tests of social behavior in a genetic model of reduced NMDA receptor function. Behav Brain Res. 2004; 153:507-519. [PubMed: 15265649]

25. Halene TB, Ehrlichman RS, Liang Y, Christian EP, Jonak GJ, Gur TL, Blendy JA, Dow HC, Brodkin ES, Schneider F, Gur RC, Siegel SJ. Assessment of NMDA receptor NR1 subunit hypofunction in mice as a model for schizophrenia. Genes Brain Behav. 2009; 8:661-675. [PubMed: 19563516]

26. Fradley RL, O’Meara GF, Newman RJ, Andrieux A, Job D, Reynolds DS. STOP knockout and NMDA NR1 hypomorphic mice exhibit deficits in sensorimotor gating. Behav Brain Res. 2005; 163:257-264. [PubMed: 16046005]

27. Moy SS, Perez A, Koller BH, Duncan GE. Amphetamine-induced disruption of prepulse inhibition in mice with reduced NMDA receptor function. Brain Res. 2006; 1089:186-194. [PubMed: 16638606]

28. Moy SS, Nikolova VD, Riddick NV, Baker LK, Koller BH. Preweaning Sensorimotor Deficits and Adolescent Hypersociability in Grin1 Knockdown Mice. Dev Neurosci. 2012

29. Gabriels RL, Cuccaro ML, Hill DE, Ivers BJ, Goldson E. Repetitive behaviors in autism: relationships with associated clinical features. Res Dev Disabil. 2005; 26:169-181. [PubMed: 15590247]

30. Boyd BA, Baranek GT, Sideris J, Poe MD, Watson LR, Patten E, Miller H. Sensory features and repetitive behaviors in children with autism and developmental delays. Autism Res. 2010; 3:7887. [PubMed: 20437603]

31. Sasson NJ, Elison JT, Turner-Brown LM, Dichter GS, Bodfish JW. Brief report: Circumscribed attention in young children with autism. J Autism Dev Disord. 2011; 41:242-247. [PubMed: 20499147]

32. Sasson NJ, Turner-Brown LM, Holtzclaw TN, Lam KS, Bodfish JW. Children with autism demonstrate circumscribed attention during passive viewing of complex social and nonsocial picture arrays. Autism Res. 2008; 1:31-42. [PubMed: 19360648]

33. Elison JT, Sasson NJ, Turner-Brown LM, Dichter G, Bodfish JW. Age Trends in Visual Exploration of Social and Nonsocial Information in Children with Autism. Res Autism Spectr Disord. 2012; 6:842-851. [PubMed: 22639682]

34. Moy SS, Nadler JJ, Young NB, Perez A, Holloway LP, Barbaro RP, Barbaro JR, Wilson LM, Threadgill DW, Lauder JM, Magnuson TR, Crawley JN. Mouse behavioral tasks relevant to autism: Phenotypes of 10 inbred strains. Behav Brain Res. 2007; 176:4-20. [PubMed: 16971002] 
35. Szatkiewicz JP, Beane GL, Ding Y, Hutchins L, Pardo-Manuel de Villena F, Churchill GA. An imputed genotype resource for the laboratory mouse. Mamm Genome. 2008; 19:199-208. [PubMed: 18301946]

36. Bailey JS, Grabowski-Boase L, Steffy BM, Wiltshire T, Churchill GA, Tarantino LM. Identification of quantitative trait loci for locomotor activation and anxiety using closely related inbred strains. Genes Brain Behav. 2008; 7:761-769. [PubMed: 19130624]

37. Eisener-Dorman AF, Grabowski-Boase L, Steffy BM, Wiltshire T, Tarantino LM. Quantitative trait locus and haplotype mapping in closely related inbred strains identifies a locus for open field behavior. Mamm Genome. 2010; 21:231-246. [PubMed: 20473506]

38. Dulawa SC, Geyer MA. Psychopharmacology of prepulse inhibition in mice. Chin J Physiol. 1996; 39:139-146. [PubMed: 8955560]

39. Paylor R, Crawley JN. Inbred strain differences in prepulse inhibition of the mouse startle response. Psychopharmacology (Berl). 1997; 132:169-180. [PubMed: 9266614]

40. Casey JP, Magalhaes T, Conroy JM, Regan R, Shah N, Anney R, Shields DC, Abrahams BS, Almeida J, Bacchelli E, Bailey AJ, Baird G, Battaglia A, Berney T, Bolshakova N, Bolton PF, Bourgeron T, Brennan S, Cali P, Correia C, Corsello C, Coutanche M, Dawson G, de Jonge M, Delorme R, Duketis E, Duque F, Estes A, Farrar P, Fernandez BA, Folstein SE, Foley S, Fombonne E, Freitag CM, Gilbert J, Gillberg C, Glessner JT, Green J, Guter SJ, Hakonarson H, Holt R, Hughes G, Hus V, Igliozzi R, Kim C, Klauck SM, Kolevzon A, Lamb JA, Leboyer M, Le Couteur A, Leventhal BL, Lord C, Lund SC, Maestrini E, Mantoulan C, Marshall CR, McConachie H, McDougle CJ, McGrath J, McMahon WM, Merikangas A, Miller J, Minopoli F, Mirza GK, Munson J, Nelson SF, Nygren G, Oliveira G, Pagnamenta AT, Papanikolaou K, Parr JR, Parrini B, Pickles A, Pinto D, Piven J, Posey DJ, Poustka A, Poustka F, Ragoussis J, Roge B, Rutter ML, Sequeira AF, Soorya L, Sousa I, Sykes N, Stoppioni V, Tancredi R, Tauber M, Thompson AP, Thomson S, Tsiantis J, Van Engeland H, Vincent JB, Volkmar F, Vorstman JA, Wallace S, Wang K, Wassink TH, White K, Wing K, Wittemeyer K, Yaspan BL, Zwaigenbaum L, Betancur C, Buxbaum JD, Cantor RM, Cook EH, Coon H, Cuccaro ML, Geschwind DH, Haines JL, Hallmayer J, Monaco AP, Nurnberger JI Jr, Pericak-Vance MA, Schellenberg GD, Scherer SW, Sutcliffe JS, Szatmari P, Vieland VJ, Wijsman EM, Green A, Gill M, Gallagher L, Vicente A, Ennis S. A novel approach of homozygous haplotype sharing identifies candidate genes in autism spectrum disorder. Hum Genet. 2011

41. Scherer SW, Dawson G. Risk factors for autism: translating genomic discoveries into diagnostics. Hum Genet. 2011; 130:123-148. [PubMed: 21701786]

42. Bishop SL, Hus V, Duncan A, Huerta M, Gotham K, Pickles A, Kreiger A, Buja A, Lund S, Lord C. Subcategories of restricted and repetitive behaviors in children with autism spectrum disorders. J Autism Dev Disord. 2013; 43:1287-1297. [PubMed: 23065116]

43. Kim SH, Lord C. Restricted and repetitive behaviors in toddlers and preschoolers with autism spectrum disorders based on the Autism Diagnostic Observation Schedule (ADOS). Autism Res. 2010; 3:162-173. [PubMed: 20589716]

44. Cuccaro ML, Shao Y, Grubber J, Slifer M, Wolpert CM, Donnelly SL, Abramson RK, Ravan SA, Wright HH, DeLong GR, Pericak-Vance MA. Factor analysis of restricted and repetitive behaviors in autism using the Autism Diagnostic Interview-R. Child Psychiatry Hum Dev. 2003; 34:3-17. [PubMed: 14518620]

45. Szatmari P, Georgiades S, Bryson S, Zwaigenbaum L, Roberts W, Mahoney W, Goldberg J, Tuff L. Investigating the structure of the restricted, repetitive behaviours and interests domain of autism. J Child Psychol Psychiatry. 2006; 47:582-590. [PubMed: 16712635]

46. Blundell J, Blaiss CA, Etherton MR, Espinosa F, Tabuchi K, Walz C, Bolliger MF, Sudhof TC, Powell CM. Neuroligin-1 deletion results in impaired spatial memory and increased repetitive behavior. J Neurosci. 2010; 30:2115-2129. [PubMed: 20147539]

47. Welch JM, Lu J, Rodriguiz RM, Trotta NC, Peca J, Ding JD, Feliciano C, Chen M, Adams JP, Luo J, Dudek SM, Weinberg RJ, Calakos N, Wetsel WC, Feng G. Cortico-striatal synaptic defects and OCD-like behaviours in Sapap3-mutant mice. Nature. 2007; 448:894-900. [PubMed: 17713528]

48. Mahajan R, Bernal MP, Panzer R, Whitaker A, Roberts W, Handen B, Hardan A, Anagnostou E, Veenstra-VanderWeele J. Clinical practice pathways for evaluation and medication choice for 
attention-deficit/hyperactivity disorder symptoms in autism spectrum disorders. Pediatrics. 2012; 130 (Suppl 2):S125-138. [PubMed: 23118243]

49. Hashimoto A, Konno R, Yano H, Yoshikawa M, Tamaki R, Matsumoto H, Kobayashi H. Mice lacking d-amino acid oxidase activity exhibit marked reduction of methamphetamine-induced stereotypy. Eur J Pharmacol. 2008; 586:221-225. [PubMed: 18448092]

50. Karler R, Calder LD, Thai DK, Bedingfield JB. The role of dopamine and GABA in the frontal cortex of mice in modulating a motor-stimulant effect of amphetamine and cocaine. Pharmacol Biochem Behav. 1998; 60:237-244. [PubMed: 9610948]

51. Logue SF, Grauer SM, Paulsen J, Graf R, Taylor N, Sung MA, Zhang L, Hughes Z, Pulito VL, Liu F, Rosenzweig-Lipson S, Brandon NJ, Marquis KL, Bates B, Pausch M. The orphan GPCR, GPR88, modulates function of the striatal dopamine system: a possible therapeutic target for psychiatric disorders? Mol Cell Neurosci. 2009; 42:438-447. [PubMed: 19796684]

52. Van Swearingen AE, Walker QD, Kuhn CM. Sex differences in novelty- and psychostimulantinduced behaviors of C57BL/6 mice. Psychopharmacology (Berl). 2013; 225:707-718. [PubMed: 22975726]

53. Seeman P, Hall FS, Uhl G. Increased dopamine D2High receptors in knockouts of the dopamine transporter and the vesicular monoamine transporter may contribute to spontaneous hyperactivity and dopamine supersensitivity. Synapse. 2007; 61:573-576. [PubMed: 17447256]

54. Zocchi A, Orsini C, Cabib S, Puglisi-Allegra S. Parallel strain-dependent effect of amphetamine on locomotor activity and dopamine release in the nucleus accumbens: an in vivo study in mice. Neuroscience. 1998; 82:521-528. [PubMed: 9466458]

55. Cabib S, Bonaventura N. Parallel strain-dependent susceptibility to environmentally-induced stereotypies and stress-induced behavioral sensitization in mice. Physiol Behav. 1997; 61:499506. [PubMed: 9108567]

56. Conversi D, Bonito-Oliva A, Orsini C, Colelli V, Cabib S. DeltaFosB accumulation in ventromedial caudate underlies the induction but not the expression of behavioral sensitization by both repeated amphetamine and stress. Eur J Neurosci. 2008; 27:191-201. [PubMed: 18184321]

57. Silverman JL, Babineau BA, Oliver CF, Karras MN, Crawley JN. Influence of stimulant-induced hyperactivity on social approach in the BTBR mouse model of autism. Neuropharmacology. 2013; 68:210-222. [PubMed: 22968082]

58. Ayhan Y, Abazyan B, Nomura J, Kim R, Ladenheim B, Krasnova IN, Sawa A, Margolis RL, Cadet JL, Mori S, Vogel MW, Ross CA, Pletnikov MV. Differential effects of prenatal and postnatal expressions of mutant human DISC1 on neurobehavioral phenotypes in transgenic mice: evidence for neurodevelopmental origin of major psychiatric disorders. Mol Psychiatry. 2011; 16:293-306. [PubMed: 20048751]

59. Silverman JL, Tolu SS, Barkan CL, Crawley JN. Repetitive self-grooming behavior in the BTBR mouse model of autism is blocked by the mGluR5 antagonist MPEP. Neuropsychopharmacology. 2010; 35:976-989. [PubMed: 20032969]

60. Balemans MC, Huibers MM, Eikelenboom NW, Kuipers AJ, van Summeren RC, Pijpers MM, Tachibana M, Shinkai Y, van Bokhoven H, Van der Zee CE. Reduced exploration, increased anxiety, and altered social behavior: Autistic-like features of euchromatin histone methyltransferase 1 heterozygous knockout mice. Behav Brain Res. 2010; 208:47-55. [PubMed: 19896504]

61. Feyder M, Karlsson RM, Mathur P, Lyman M, Bock R, Momenan R, Munasinghe J, Scattoni ML, Ihne J, Camp M, Graybeal C, Strathdee D, Begg A, Alvarez VA, Kirsch P, Rietschel M, Cichon S, Walter H, Meyer-Lindenberg A, Grant SG, Holmes A. Association of mouse Dlg4 (PSD-95) gene deletion and human DLG4 gene variation with phenotypes relevant to autism spectrum disorders and Williams' syndrome. Am J Psychiatry. 2010; 167:1508-1517. [PubMed: 20952458]

62. DeLorey TM, Sahbaie P, Hashemi E, Li WW, Salehi A, Clark DJ. Somatosensory and sensorimotor consequences associated with the heterozygous disruption of the autism candidate gene, Gabrb3. Behav Brain Res. 2011; 216:36-45. [PubMed: 20699105]

63. Frankland PW, Wang Y, Rosner B, Shimizu T, Balleine BW, Dykens EM, Ornitz EM, Silva AJ. Sensorimotor gating abnormalities in young males with fragile $\mathrm{X}$ syndrome and Fmr1-knockout mice. Mol Psychiatry. 2004; 9:417-425. [PubMed: 14981523] 
64. McAlonan GM, Daly E, Kumari V, Critchley HD, van Amelsvoort T, Suckling J, Simmons A, Sigmundsson T, Greenwood K, Russell A, Schmitz N, Happe F, Howlin P, Murphy DG. Brain anatomy and sensorimotor gating in Asperger's syndrome. Brain. 2002; 125:1594-1606. [PubMed: 12077008]

65. Perry W, Minassian A, Lopez B, Maron L, Lincoln A. Sensorimotor gating deficits in adults with autism. Biol Psychiatry. 2007; 61:482-486. [PubMed: 16460695]

66. Chen L, Toth M. Fragile X mice develop sensory hyperreactivity to auditory stimuli. Neuroscience. 2001; 103:1043-1050. [PubMed: 11301211]

67. Paylor R, Yuva-Paylor LA, Nelson DL, Spencer CM. Reversal of sensorimotor gating abnormalities in Fmr1 knockout mice carrying a human Fmr1 transgene. Behav Neurosci. 2008; 122:1371-1377. [PubMed: 19045956]

68. Pierce K, Courchesne E. Evidence for a cerebellar role in reduced exploration and stereotyped behavior in autism. Biol Psychiatry. 2001; 49:655-664. [PubMed: 11313033]

69. Penagarikano O, Abrahams BS, Herman EI, Winden KD, Gdalyahu A, Dong H, Sonnenblick LI, Gruver R, Almajano J, Bragin A, Golshani P, Trachtenberg JT, Peles E, Geschwind DH. Absence of CNTNAP2 leads to epilepsy, neuronal migration abnormalities, and core autism-related deficits. Cell. 2011; 147:235-246. [PubMed: 21962519]

70. Li W, Zhou Y, Jentsch JD, Brown RA, Tian X, Ehninger D, Hennah W, Peltonen L, Lonnqvist J, Huttunen MO, Kaprio J, Trachtenberg JT, Silva AJ, Cannon TD. Specific developmental disruption of disrupted-in-schizophrenia-1 function results in schizophrenia-related phenotypes in mice. Proc Natl Acad Sci U S A. 2007; 104:18280-18285. [PubMed: 17984054]

71. Moy SS, Nadler JJ, Young NB, Nonneman RJ, Grossman AW, Murphy DL, D'Ercole AJ, Crawley JN, Magnuson TR, Lauder JM. Social Approach in Genetically-Engineered Mouse Lines Relevant to Autism. Genes Brain Behav. 2009; 8:129-142. [PubMed: 19016890]

72. DeLorey TM, Sahbaie P, Hashemi E, Homanics GE, Clark JD. Gabrb3 gene deficient mice exhibit impaired social and exploratory behaviors, deficits in non-selective attention and hypoplasia of cerebellar vermal lobules: a potential model of autism spectrum disorder. Behav Brain Res. 2008; 187:207-220. [PubMed: 17983671]

73. Fatemi SH, Reutiman TJ, Folsom TD, Rooney RJ, Patel DH, Thuras PD. mRNA and protein levels for GABAAalpha4, alpha5, beta1 and GABABR1 receptors are altered in brains from subjects with autism. J Autism Dev Disord. 2010; 40:743-750. [PubMed: 20066485]

74. Carneiro AM, Airey DC, Thompson B, Zhu CB, Lu L, Chesler EJ, Erikson KM, Blakely RD. Functional coding variation in recombinant inbred mouse lines reveals multiple serotonin transporter-associated phenotypes. Proc Natl Acad Sci U S A. 2009; 106:2047-2052. [PubMed: 19179283]

75. Brodkin ES, Hagemann A, Nemetski SM, Silver LM. Social approach-avoidance behavior of inbred mouse strains towards DBA/2 mice. Brain Res. 2004; 1002:151-157. [PubMed: 14988045]

76. Sankoorikal GM, Kaercher KA, Boon CJ, Lee JK, Brodkin ES. A mouse model system for genetic analysis of sociability: C57BL/6J versus BALB/cJ inbred mouse strains. Biol Psychiatry. 2006; 59:415-423. [PubMed: 16199013]

77. O'Roak BJ, Deriziotis P, Lee C, Vives L, Schwartz JJ, Girirajan S, Karakoc E, Mackenzie AP, Ng SB, Baker C, Rieder MJ, Nickerson DA, Bernier R, Fisher SE, Shendure J, Eichler EE. Exome sequencing in sporadic autism spectrum disorders identifies severe de novo mutations. Nat Genet. 2011; 43:585-589. [PubMed: 21572417]

78. Bakkaloglu B, O’Roak BJ, Louvi A, Gupta AR, Abelson JF, Morgan TM, Chawarska K, Klin A, Ercan-Sencicek AG, Stillman AA, Tanriover G, Abrahams BS, Duvall JA, Robbins EM, Geschwind DH, Biederer T, Gunel M, Lifton RP, State MW. Molecular cytogenetic analysis and resequencing of contactin associated protein-like 2 in autism spectrum disorders. Am J Hum Genet. 2008; 82:165-173. [PubMed: 18179895] 


\section{Highlights}

The C58/J inbred mouse strain was supersensitive to locomotor effects of amphetamine.

Both C58/J and Grinl knockdown mice had overt deficits in the marble-burying task.

$\mathrm{C} 58 / \mathrm{J}$ had reduced exploration and altered olfactory preference in a nose-poke test.

Strain genome comparisons identified 97 autism candidate genes divergent in C58/J. 


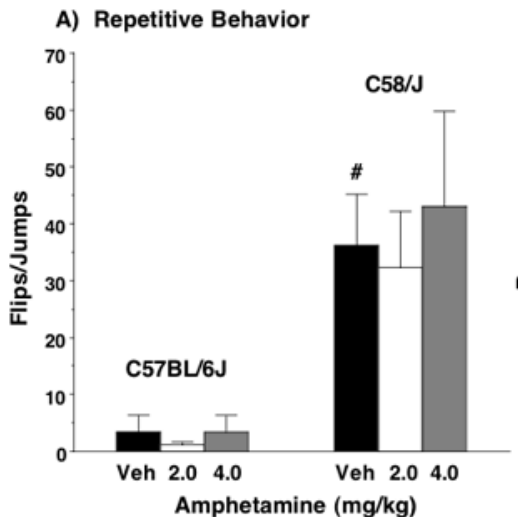

B) Rearing Movements

\section{C) Locomotor Activity}
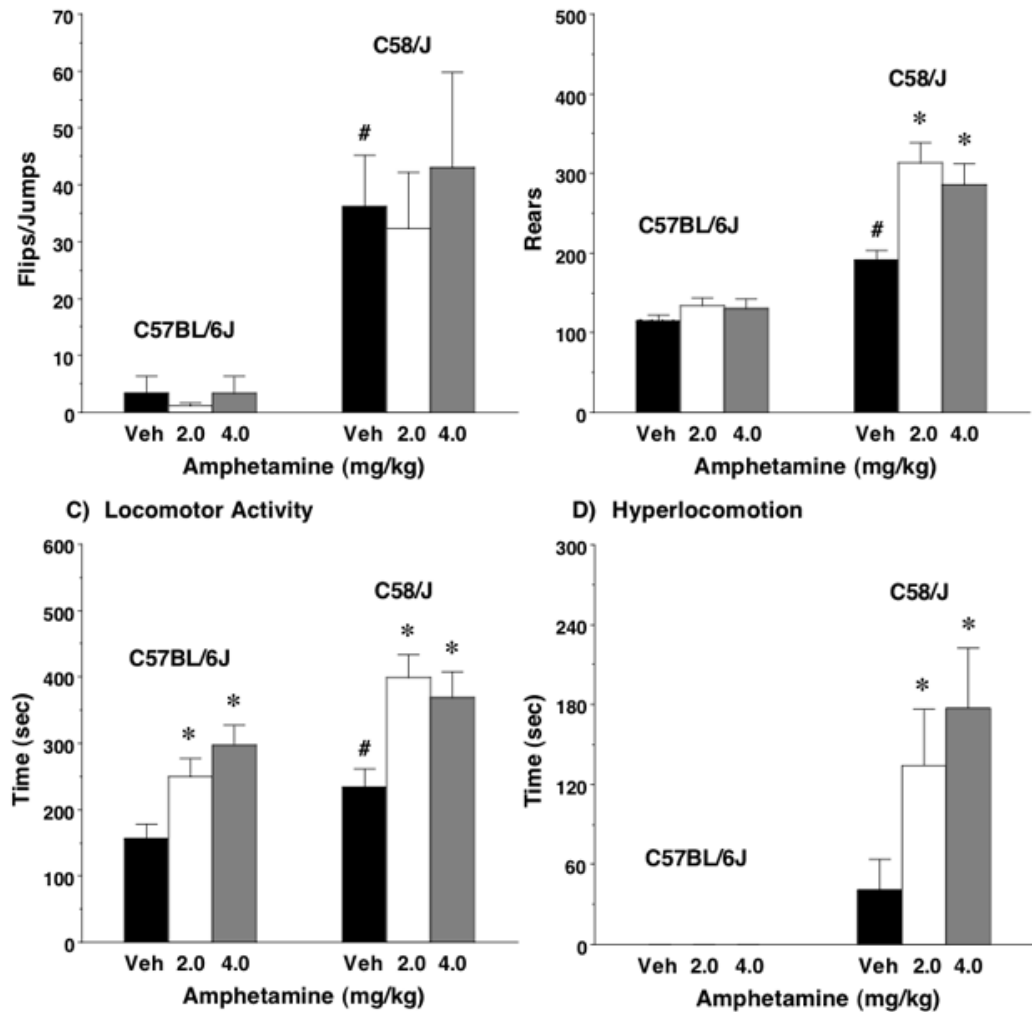

D) Hyperlocomotion

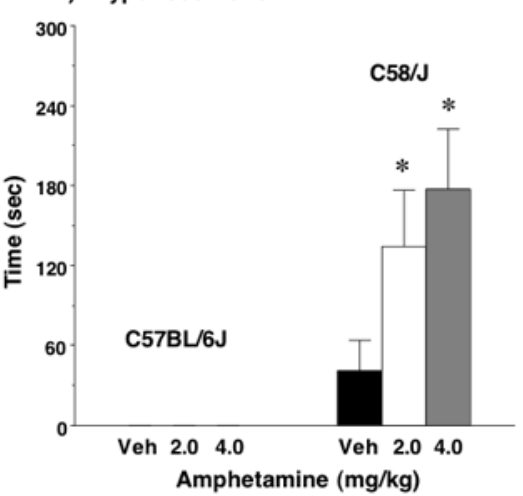

E) Time Spent Grooming
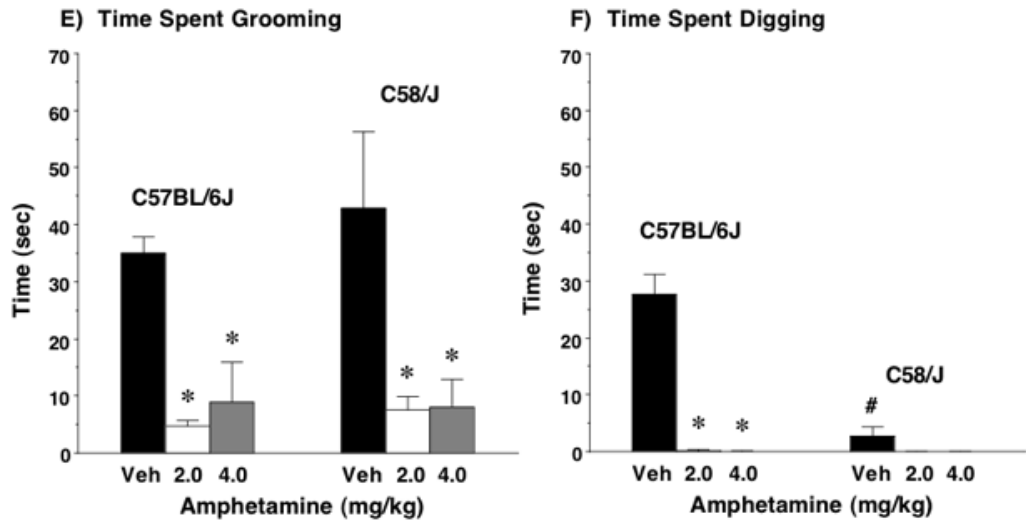

Figure 1. Amphetamine effects on behavior during an observational screen

Data shown are means (+SEM) for a 10-min session. Statistical strain comparisons were not conducted for the measure of hyperlocomotion, since this behavior did not occur in the C57BL/6J mice. \#p<0.05, between-strain comparison to vehicle-treated C57BL/6J (post-hoc test for baseline strain differences). ${ }^{*} \mathrm{p}<0.05$, within-strain comparison between each dose of amphetamine and vehicle. 
A)

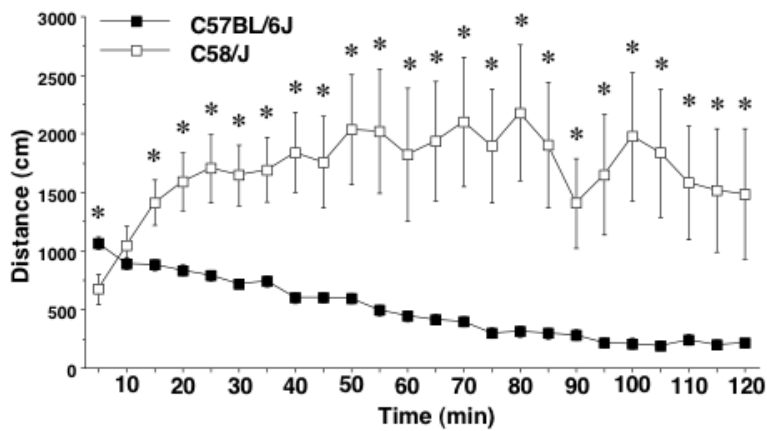

C)

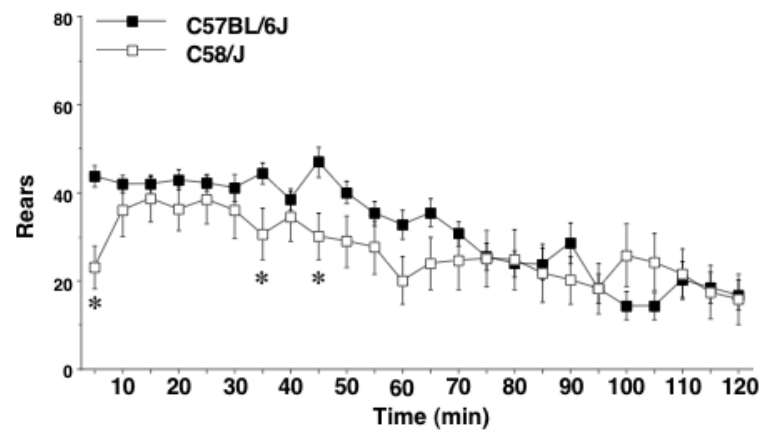

B)

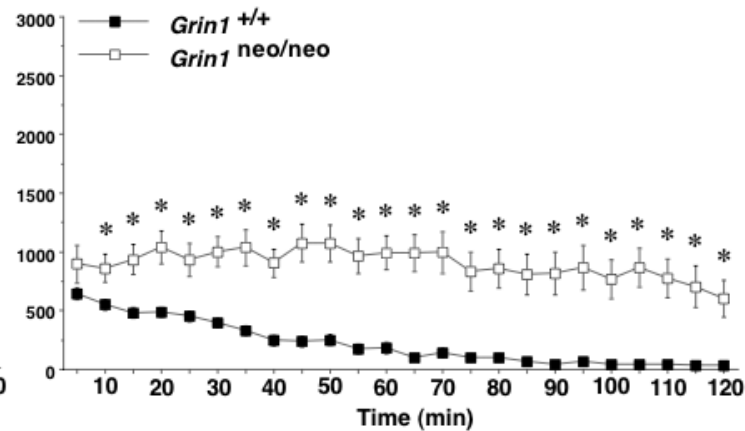

D)

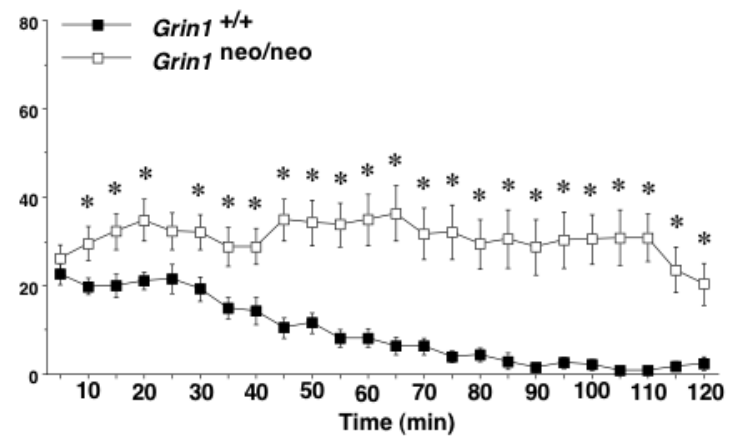

Figure 2. Distance traveled and numbers of rearing movements in C58/J and Grin ${ }^{\text {neo/neo }}$ mice $^{\text {. }}$ Hyperlocomotion was observed in both models for repetitive behavior. Data are means $( \pm$ SEM) for a 2-hr test in a novel open field. Data from one female C58/J mouse were excluded because of lighting malfunction in the test box. $* \mathrm{p}<0.05$. 
A) Distance Traveled: Vehicle

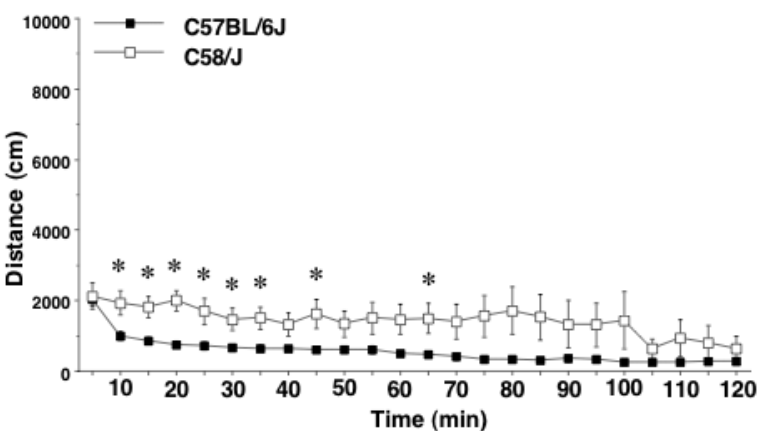

C) Rearing Movements: Vehicle

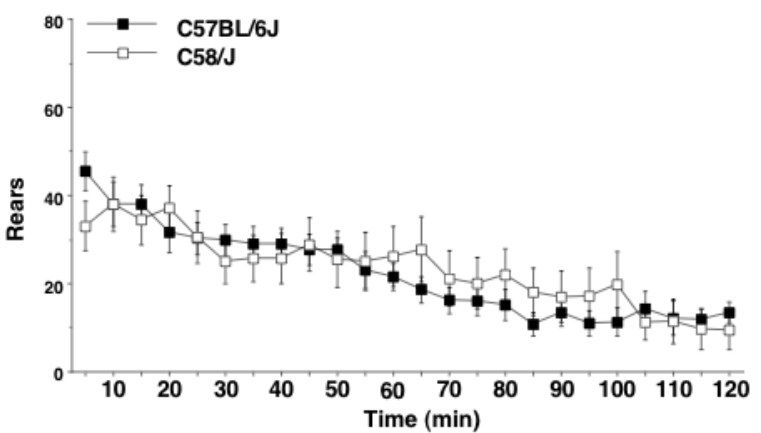

B) Distance Traveled: Amphetamine

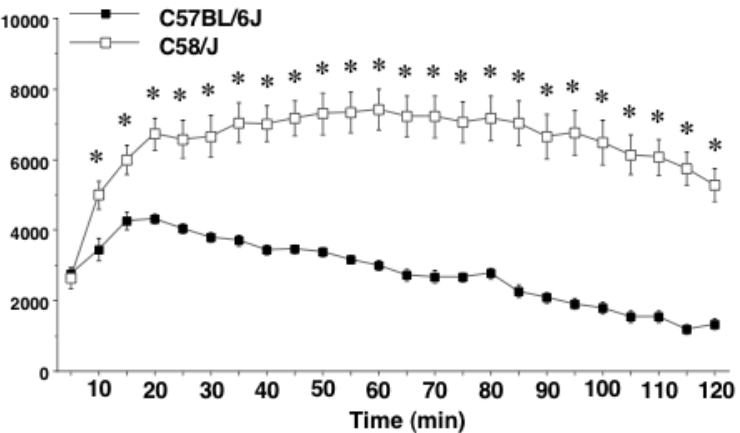

D) Rearing Movements: Amphetamine

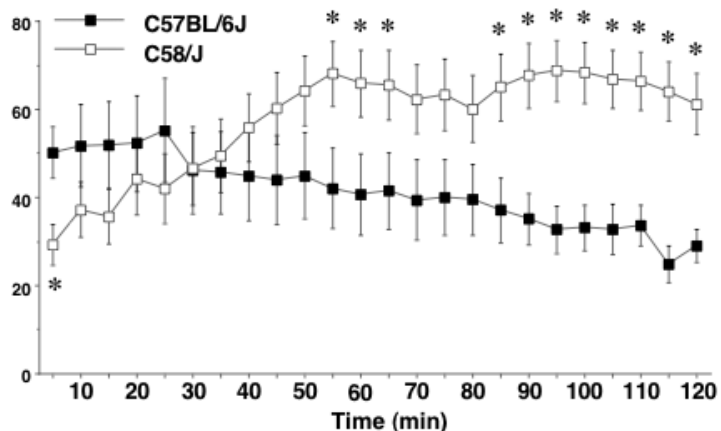

Figure 3. Supersensitivity to stimulant effects of amphetamine in $\mathbf{C 5 8} / \mathbf{J}$ mice

A, B) Scale for $y$ axis was adjusted from that used in Figure 2A, B to accommodate higher levels of locomotion in C58/J mice treated with amphetamine $(4 \mathrm{mg} / \mathrm{kg})$. Data are means $( \pm$ SEM) for a $2-\mathrm{hr}$ test in a novel open field. *p<0.05. 

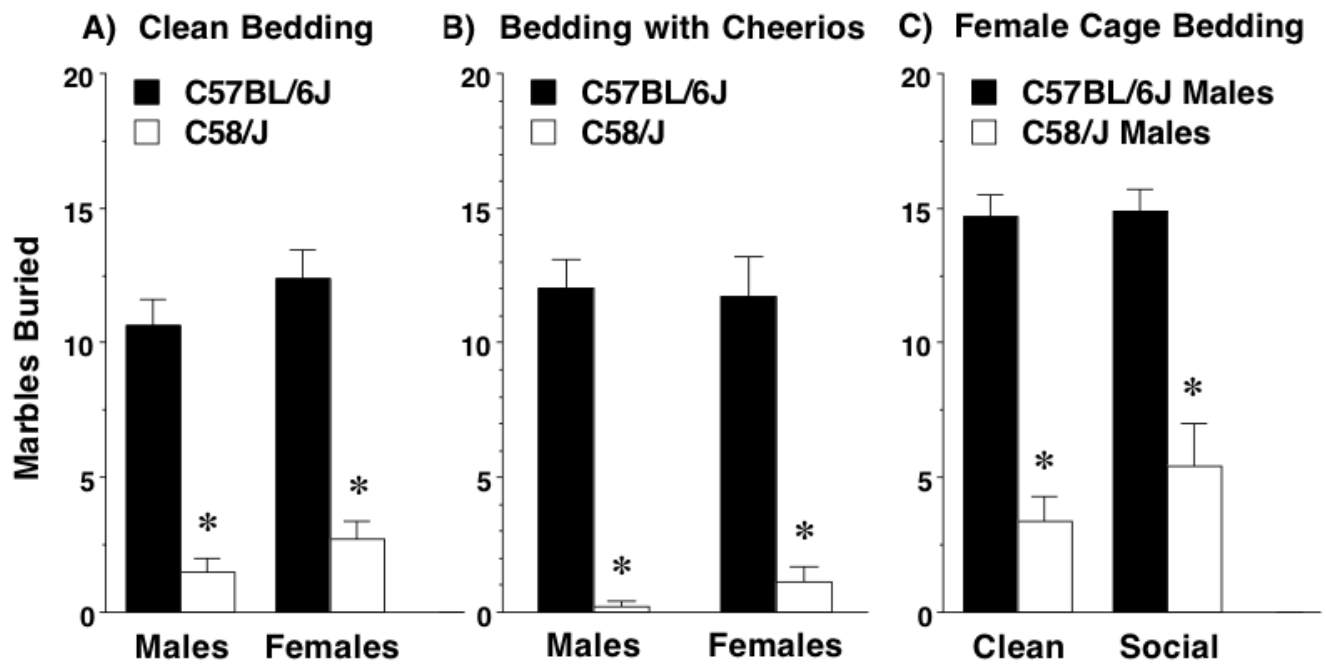

D) Knockdown Model

E) NMDA Antagonist
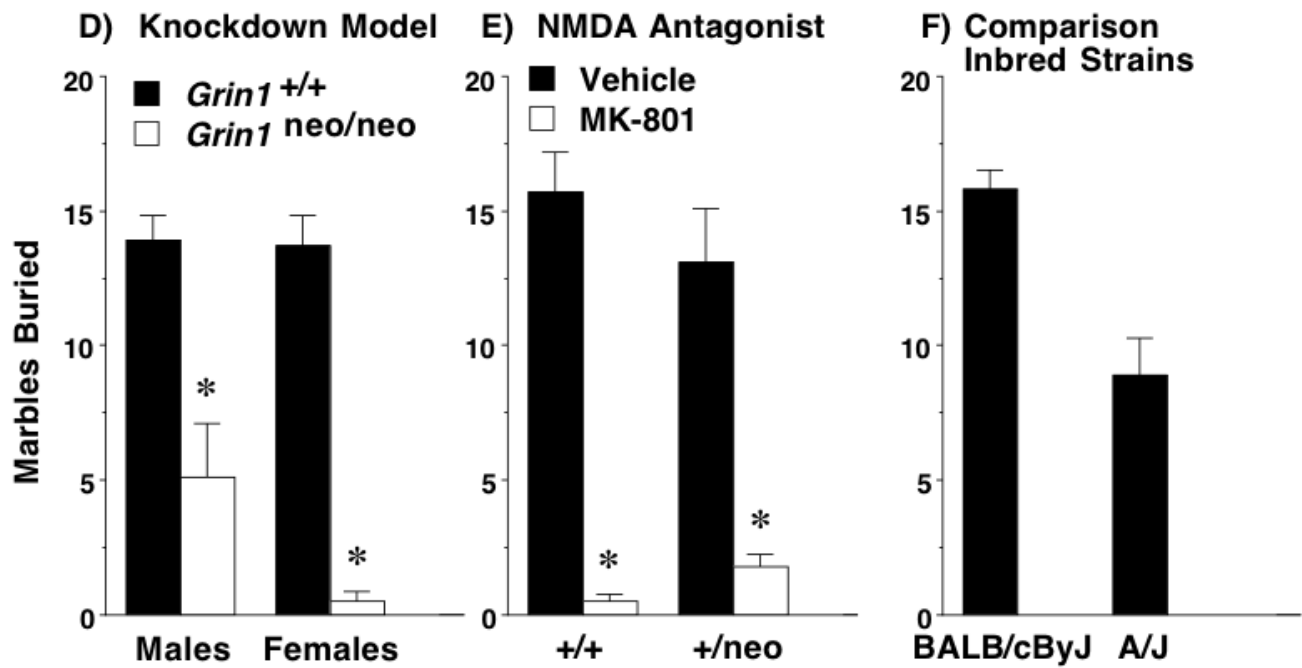

Figure 4. Reduced marble-burying in $\mathrm{C58} / \mathrm{J}$ and Grin1 ${ }^{\text {neo/neo }}$ mice

A-E) Data are means (+ SEM) for a 30-min test with 20 marbles. B) Cheerios were buried under approximately 2-3 cm of clean bedding. C) Male C57BL/6J and C58/J mice were tested in a cage in which a layer of bedding, taken from a home cage housing female mice, was buried under approximately $2-3 \mathrm{~cm}$ of clean bedding. D) MK-801 $(0.2 \mathrm{mg} / \mathrm{kg})$ was administered to Grinl wild-type and heterozygous mice $5 \mathrm{~min}$ before the start of the test. Data from one male C57BL/6J mouse (Panel A) were excluded because of lighting malfunction. ${ }^{*} \mathrm{p}<0.05$. 

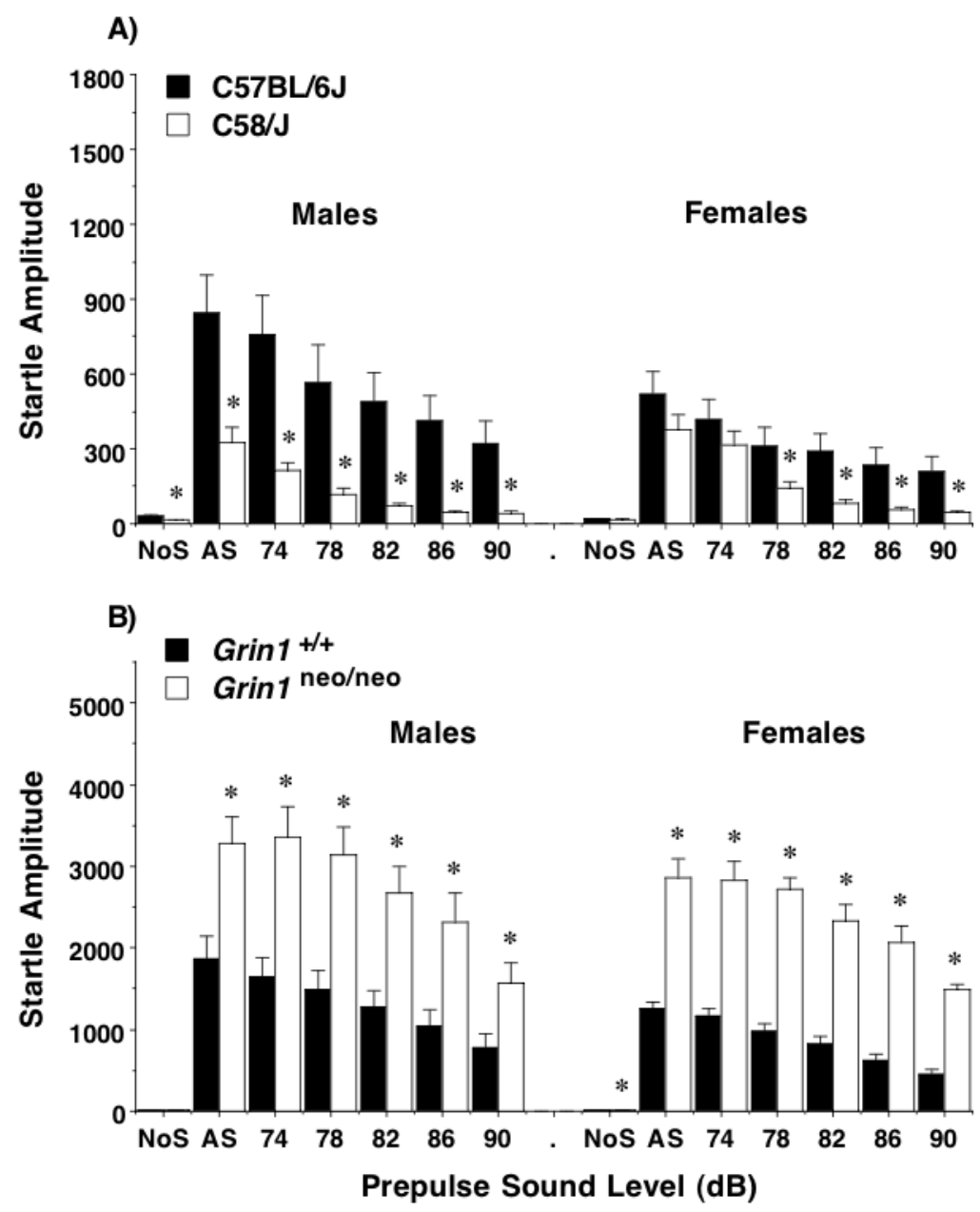

Figure 5. Response amplitudes in the acoustic startle test

Opposite patterns were observed in the C58/J and Grin $1^{\text {neo/neo }}$ mice. The very high startle responses in the Grin $1^{\text {neo/neo }}$ mice necessitated different scales of measure for the y axes of the two panels. Data shown are means (+ SEM) for each group. Trials included no stimulus (No S) trials and acoustic startle stimulus (AS; $120 \mathrm{~dB})$ alone trials. *p $<0.05$. 

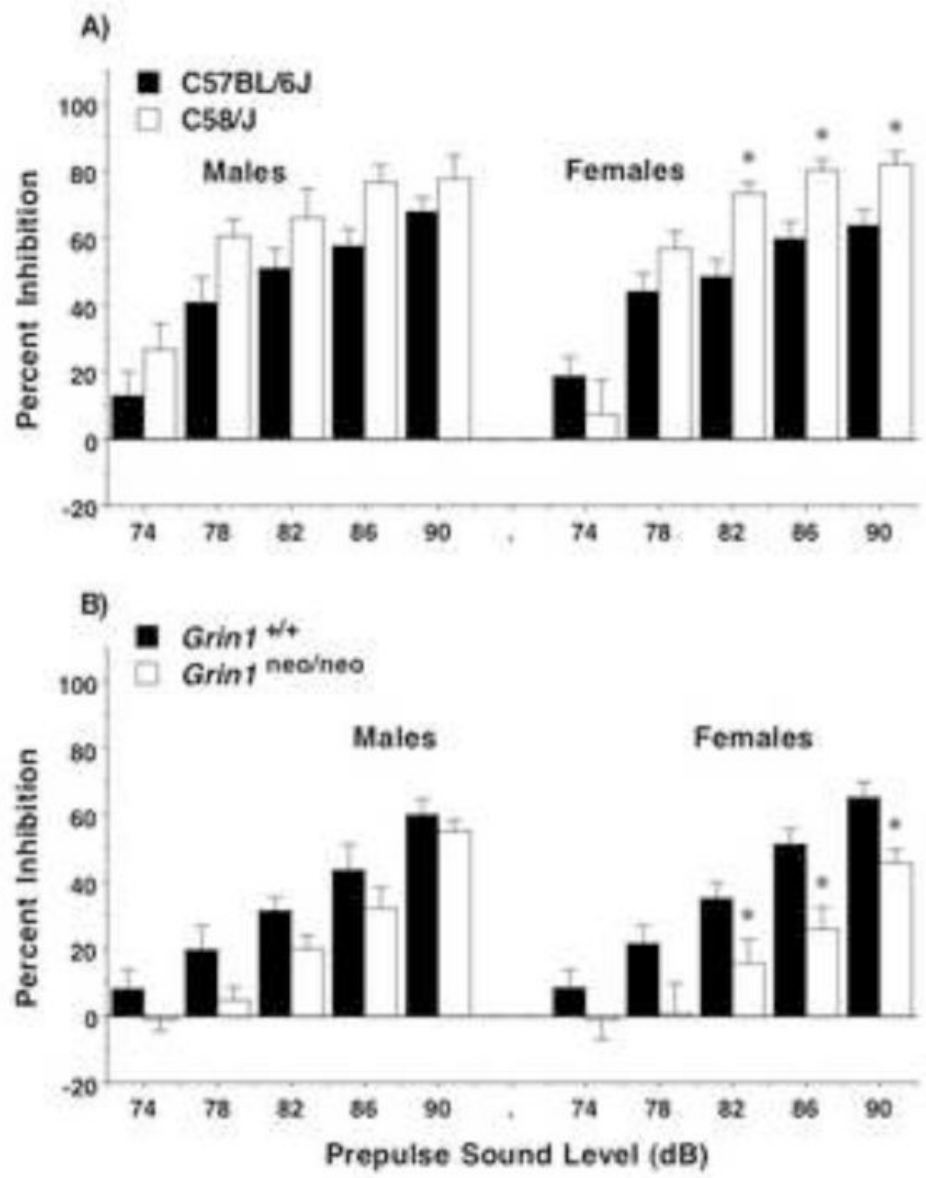

Figure 6. Prepulse inhibition of acoustic startle responses

Female C58/J mice had significant increases in percent inhibition, while female $G r i n 1^{\text {neo/neo }}$ mice showed the opposite pattern. Data shown are means (+ SEM) for each group. ${ }^{*} \mathrm{p}<$ 0.05 . 


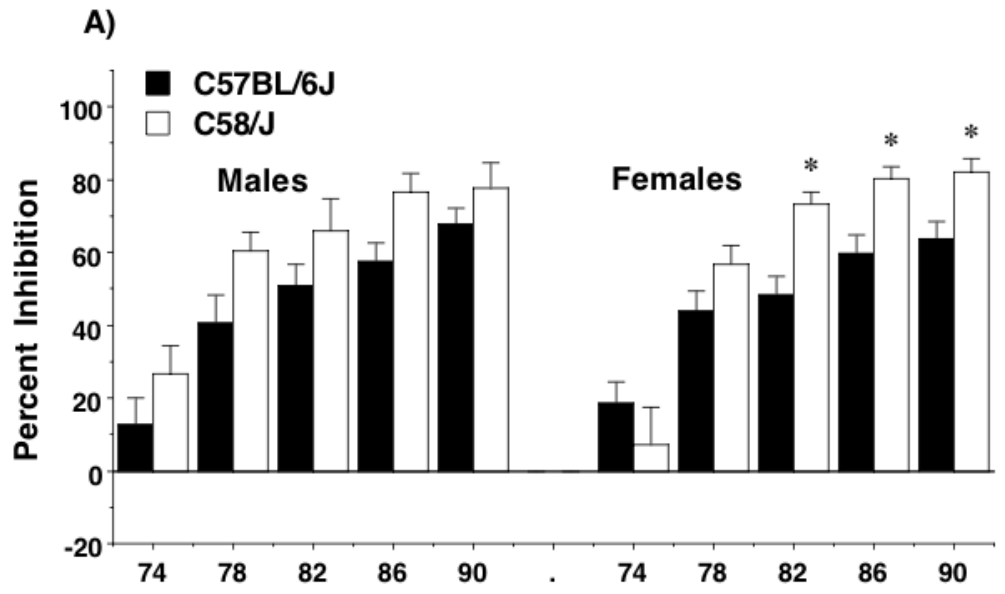

\section{B)}

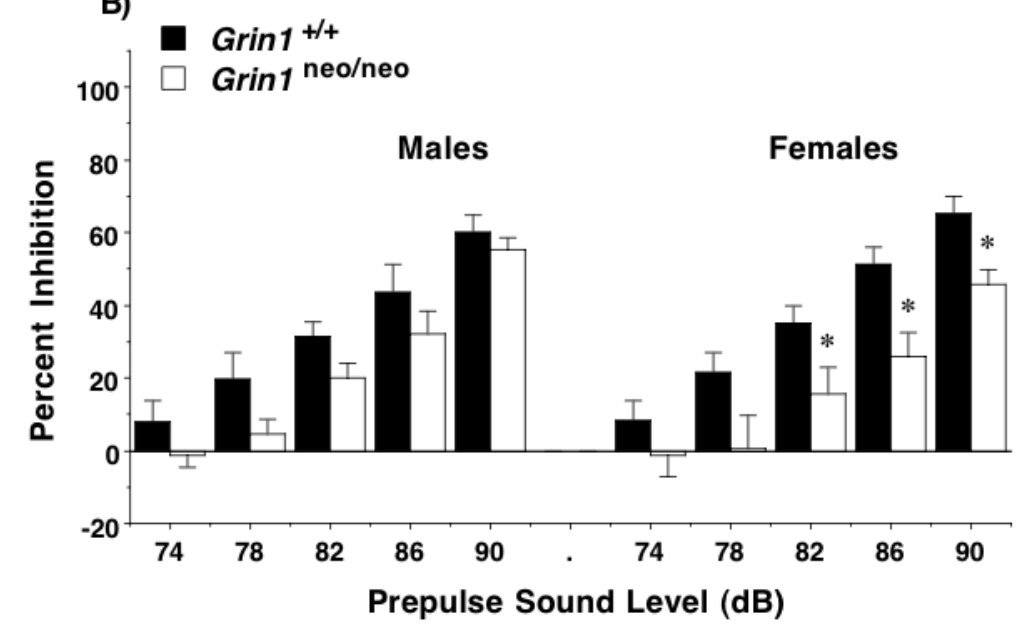

Figure 7. Hole preference and number of nose pokes in three inbred mouse strains A) None of the group means reached criterion levels for preference during the first exploration test. B) Holeboard numbering system in the activity chamber. With equal distribution of responses across holes, average values for percent of total nose pokes would equal $6.25 \%$ per hole. Criterion for high preference was set at two times the average value $(12.5 \%)$, and extreme preference was set at three times the average value $(18.75 \%)$. C) Number of nose pokes during each one-hour test. No olfactory stimuli were presented in the first two tests, given one day apart. Olfactory tests 1 and 2 were conducted before and after a 2-day familiarization with chocolate chips, presented in the home cages. The final olfactory test examined preference for a novel social stimulus (CD-1 male urine). Data shown are means (+SEM). * $\mathrm{p}<0.05$, comparison to C57BL/6J. **p $<0.05$, comparison to both other strains. 
A) Before Familiarization

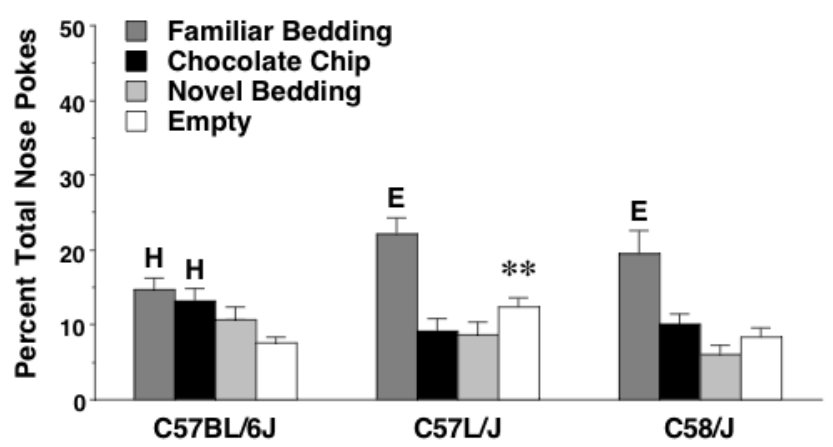

B) After Familiarization

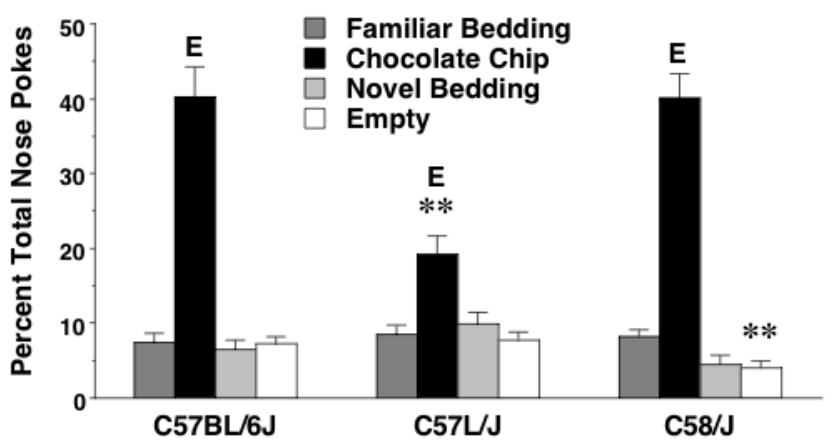

C) Preference for Social Olfactory Stimuli

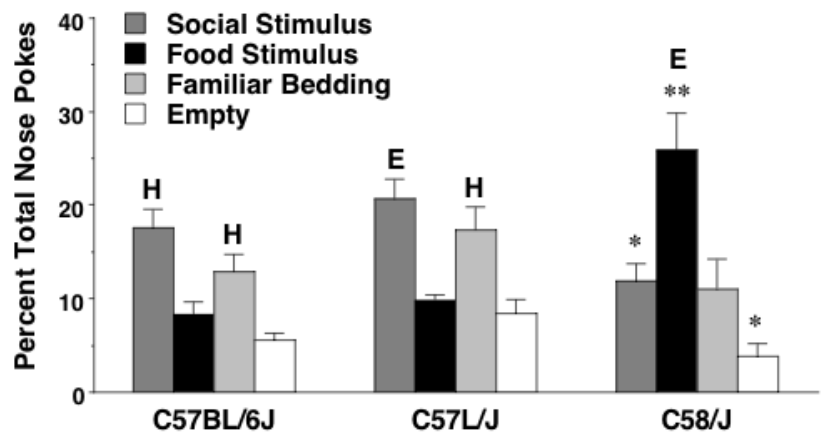

Figure 8. Olfactory preference during a nose poke task in three inbred mouse strains Olfactory stimuli were presented in the center holes. Familiarization was conducted by a 2day presentation of chocolate chips in the home cages. The average level of preference expected with equal distribution across holes was $6.25 \%$ nose pokes per hole. Criterion levels for preference were $12.5 \%(\mathbf{H}$; High) and $18.75 \%$ (E; Extreme). Data shown are means (+SEM). $* \mathrm{p}<0.05$, comparison to C57L/J. **p<0.05, comparison to both other strains. 


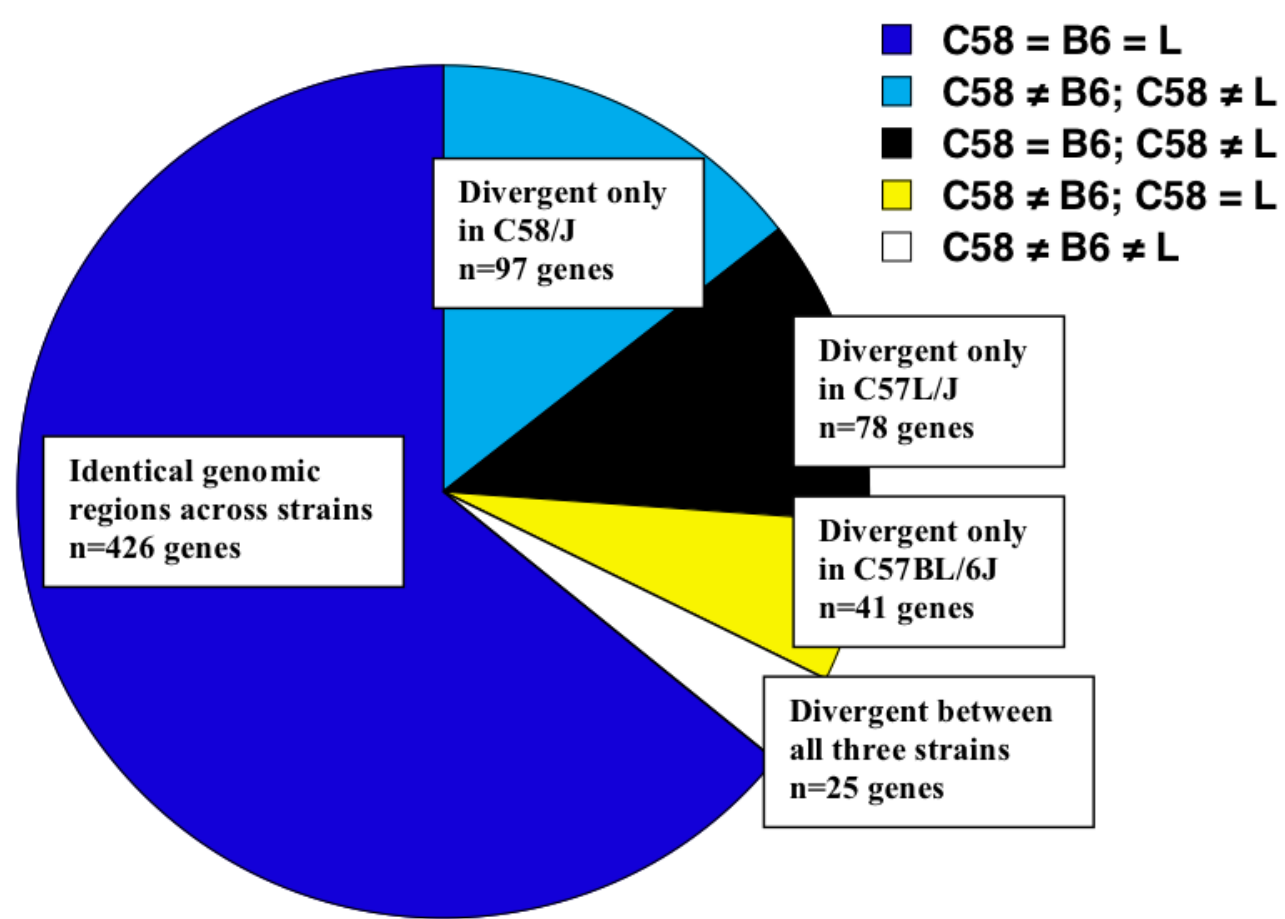

Figure 9. Distribution of mouse homologs for 667 ASD candidate genes in either identical (i.e. $\mathrm{C58}=\mathrm{B6}=\mathrm{L}$ ) or divergent genomic regions in three inbred strains

Overall set of ASD (autism spectrum disorder) candidate genes was taken from published genetic analyses in human populations [40] or literature review [41]. Strains were C58/J (C58), C57BL/6J (B6), and C57L/J (L). 


\section{Table 1}

Weight and performance on an elevated plus maze and open field in male mice from three inbred strains $(\mathrm{N}=10$ per strain). Data shown are means \pm SEM. Mice were 3-4 weeks in age when weighed, and 4-5 weeks when tested for anxiety-like behavior and activity.

\begin{tabular}{|c|c|c|c|}
\hline & C57BL/6J & C57L/J & $\mathbf{C 5 8} / \mathrm{J}$ \\
\hline Body weight (g) & $16.7 \pm 0.4$ & $16.7 \pm 0.4$ & $16.3 \pm 0.4$ \\
\hline \multicolumn{4}{|l|}{ Elevated plus maze } \\
\hline Percent open arm time & $30 \pm 2$ & $48 \pm 2^{* *}$ & $24 \pm 4$ \\
\hline Percent open arm entries & $33 \pm 2$ & $45 \pm 2^{* *}$ & $23 \pm 3^{* *}$ \\
\hline Total number of entries & $21 \pm 1$ & $42 \pm 3^{* *}$ & $21 \pm 3$ \\
\hline \multicolumn{4}{|l|}{ Open field (one hour) } \\
\hline Distance traveled $(\mathrm{cm})$ & $7,797 \pm 484$ & $10,046 \pm 683$ & $12,314 \pm 1,239^{*}$ \\
\hline Time in center $(\mathrm{sec})$ & $425 \pm 75$ & $950 \pm 69^{* *}$ & $528 \pm 78$ \\
\hline 0.05 , comparison to $\mathrm{C} 57 \mathrm{~B}$ & & & \\
\hline
\end{tabular}




\section{Table 2}

Divergence of candidate genes for autism spectrum disorder (ASD) in the C58/J inbred mouse strain, in comparison to C57BL/6J and C57L/J. Table shows examples of genes associated with neurotransmission, synaptic function, and syndromic developmental disorders, taken from a total of 667 ASD-associated genes in the single-nucleotide polymorphism (SNP) analysis.

\begin{tabular}{|c|c|}
\hline ASD Candidate Gene & Gene Name \\
\hline \multicolumn{2}{|c|}{ Mouse homolog divergent in C58/J, but not in C57BL/6J or $\mathrm{C} 57 \mathrm{~L} / \mathrm{J}$} \\
\hline CACNAIC & Calcium channel, voltage-dependent, L type, alpha 1C subunit \\
\hline CNTNAP2 & Contactin associated protein-like 2 \\
\hline DISCl & Disrupted in schizophrenia 1 \\
\hline GABRA5 & Gamma-aminobutyric acid (GABA) A receptor, alpha 5 \\
\hline GABRBI & Gamma-aminobutyric acid (GABA) A receptor, beta 1 \\
\hline$N R G 2$ & Neuregulin 2 \\
\hline SLC6A4 & Solute carrier family 6 (neurotransmitter transporter, serotonin) member 4 \\
\hline TPH2 & Tryptophan hydroxylase 2 (regulator of serotonin biosynthesis) \\
\hline \multicolumn{2}{|c|}{ Mouse homolog divergent between all three strains } \\
\hline AUTS2 & Autism susceptibility candidate 2 \\
\hline GABRB3 & Gamma-aminobutyric acid A receptor, beta 3 \\
\hline \multicolumn{2}{|c|}{ Mouse homolog identical by state in all three strains } \\
\hline$B D N F$ & Brain derived neurotrophic factor \\
\hline EN2 & Engrailed-2 \\
\hline FMRI & Fragile $x$ mental retardation 1 \\
\hline GRIN1 & Glutamate receptor, ionotropic, $N$-methyl D-aspartate 1 \\
\hline MAOA & Monoamine oxidase A \\
\hline$M E C P 2$ & Methyl-CpG-binding protein 2 \\
\hline$N F 1$ & Neurofibromatosis 1 \\
\hline$N L G N 1$ and $N L G N 3$ & Neuroligin 1 and 3 \\
\hline NRCAM & Neuronglial related cell adhesion molecule \\
\hline$O X T$ & Oxytocin \\
\hline$R E L N$ & Reelin \\
\hline SAPAP3 & SAP90/PSD95-associated protein 3 \\
\hline SHANK1 & SH3/ankyrin domain gene 1 \\
\hline SLITRK5 & SLIT and NTRK-like family, member 5 \\
\hline$T S C 1$ and $T S C 2$ & Tuberous sclerosis 1 and 2 \\
\hline$U B E 3 A$ & Ubiquitin protein ligase E3A \\
\hline
\end{tabular}

